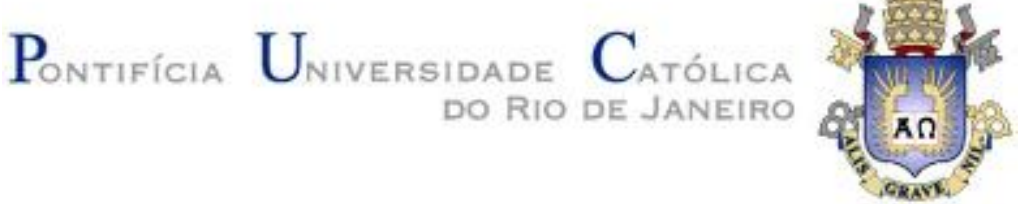

Silvia Regina Goldgaber Borges

\author{
Intervenções em Bacias Hidrográficas \\ Urbanas no Rio de Janeiro: \\ O Desvio Do Rio Joana e Reservatórios
}

Dissertação de Mestrado

Dissertação apresentada ao Programa de PósGraduação em Engenharia Urbana e Ambiental PUCRio como requisito parcial para a obtenção do título de Mestre Em Engenharia Urbana e Ambiental (opção profissional).

Orientador: Prof. Celso Romanel Coorientador: Prof. Ernani de Souza Costa

Rio de Janeiro Julho de 2013 


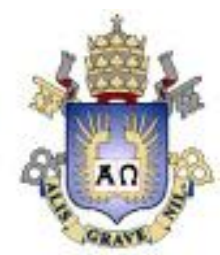

Silvia Regina Goldgaber Borges

\section{Intervenções em Bacias Hidrográficas Urbanas no Rio de Janeiro: O Desvio Do Rio Joana e Reservatórios}

Dissertação apresentada como requisito parcial para obtenção do título de Mestre em Engenharia Urbana e Ambiental (opção profissional) pelo Programa de Pós-Graduação em Engenharia Civil da PUC-Rio. Aprovada pela Comissão Examinadora abaixo assinada.

Prof. Celso Romanel

Presidente / Orientador

Departamento de Engenharia Civil - PUC-Rio

Prof. Ernani de Souza Costa

Coorientador

PUC-Rio

Prof. Tácio Mauro Pereira de Campos

Departamento de Engenharia Civil - PUC-Rio

Prof. Paulo Luiz da Fonseca

Prefeitura da Cidade do Rio de Janeiro

Prof. José Eugenio Leal

Coordenador Setorial de Pós-Graduação

do Centro Técnico Científico - PUC-Rio

Rio de Janeiro, 12 de julho de 2013. 
Todos os direitos reservados. É proibida a reprodução total ou parcial do trabalho sem autorização do autor, do orientador e da universidade.

\section{Silvia Regina Goldgaber Borges}

Graduada em Matemática pela FAHUPE e Engenharia Civil pela UGF. Cursou Métodos Computacionais em Engenharia Civil na UERJ. Pós Graduada em Gestão de Bacias Hidrográficas pela UFRJ e em Engenharia Urbana e Ambiental (Mestrado Profissional) pela PUC Rio. Participou em projetos na área petroquímica e de petróleo. Fiscalizou obras públicas de escolas e hospitais pela RioUrbe, construção de Eco Barreiras, Píer de largada e raias Albano para remo do PANAMERICANO na Lagoa Rodrigo de Freitas para a SERLA. Atualmente é fiscal na execução do Desvio do Rio Joana para a Fundação Rio-Águas. Áreas de interesse: engenharia urbana, ambiental e saneamento básico.

Ficha Catalográfica

Borges, Silvia Regina Goldgaber

Intervenções em bacias hidrográficas urbanas no Rio de Janeiro: o desvio do Rio Joana e reservatórios / Silvia Regina Goldgaber Borges; orientador: Celso Romanel; co- orientador: Ernani de Souza Costa. - 2013.

82 f. : il. (color.) ; $30 \mathrm{~cm}$

Dissertação (mestrado)-Pontifícia Universidade Católica do Rio de Janeiro, Departamento de Engenharia Civil, 2013. Inclui bibliografia

1. Engenharia civil - Teses. 2. Engenharia urbana e ambiental. 3. Gestão de recursos hídricos. 4. Manejo hídrico de bacias hidrográficas. 5. Método para planejamento e controle de enchentes. 6. Hidrologia. 7. Água. 8. Desenvolvimento urbano. 9. Sustentabilidade. I. Romanel, Celso. II. Costa, Ernani de Souza. III. Pontifícia Universidade Católica do Rio de Janeiro. Departamento de Engenharia Civil. Programa de Pós-Graduação em Engenharia Urbana e Ambiental. IV. Título. 
Aos meus filhos Tatiana, Yuri e ao meu marido José. 


\section{Agradecimentos}

A toda equipe do Programa de Pós-Graduação em Engenharia Urbana e Ambiental do Departamento de Engenharia Civil da PUC-Rio.

Aos colegas e amigos da Fundação Rio-Águas.

À minha incentivadora e amiga Liane Rangel de Moraes Vieira.

À Fundação Rio-Águas e a Mendes Junior Engenharia Ltda., pelas informações e dados fornecidos, em especial ao Eng. Eugenio Monteiro.

Aos amigos e a todos que me acompanharam nesta trajetória, o meu muito obrigado. 


\section{Resumo}

Borges, Silvia Regina Goldgaber; Romanel, Celso (Orientador); Costa, Ernani de Souza (Coorientador). Intervenções em Bacias Hidrográficas Urbanas no Rio de Janeiro: O desvio do Rio Joana e Reservatórios. Rio de Janeiro, 2013. 82p. Dissertação de Mestrado - Departamento de Engenharia Civil, Pontifícia Universidade Católica do Rio de Janeiro.

$\mathrm{Na}$ maior parte das bacias hidrográficas do mundo, observa-se a ocupação intensiva, com usos inadequados do solo e da água. No Brasil, a situação não é diferente, onde se constata graves problemas de deslizamentos de encostas e enchentes. Assim, esse trabalho pretende contribuir para as intervenções em bacias hidrográficas urbanas, baseada nos princípios do desenvolvimento sustentável. A área de estudo adotada é a Bacia Hidrográfica do Rio Joana, localizada nos bairros do Andaraí, Tijuca, Vila Isabel e Maracanã, que foi objeto de projeto piloto, sub-bacia do Canal do Mangue, uma das bacias mais antigas urbanizadas e problemáticas da cidade. O projeto citado apresenta avaliação e diagnóstico do regime do rio; da forma de ocupação da bacia; dos impactos ambientais gerados; dos efeitos das enchentes, dentre outros. Buscou-se, através de pesquisa bibliográfica em documentos históricos e em outras fontes, elucidar as origens e desenvolvimento dos problemas enfrentados atualmente na bacia e melhor compreender o processo de ocupação/uso do solo e os seus impactos sobre os recursos naturais. Constata-se a necessidade de implantar uma gestão integrada do uso da água, do solo e do saneamento básico apoiados em programas de educação ambiental.

\section{Palavras-Chave}

Gestão de Recursos Hídricos; Manejo Hídrico de Bacias Hidrográficas; Método para Planejamento e Controle de Enchentes; Hidrologia; Água; Urbanismo; Desenvolvimento Urbano; Engenharia Urbana e Ambiental; Sustentabilidade. 


\section{Abstract}

Borges, Silvia Regina Goldgaber; Romanel, Celso (Advisor); Costa, Ernani de Souza (Coadvisor). Interventions in Urban Watershed Basin in Rio de Janeiro: the deviation of Joan River and Reservoirs. Rio de Janeiro, 2013. 82p. MSc. Dissertation - Departamento de Engenharia Civil, Pontifícia Universidade Católica do rio de Janeiro.

This research seeks to provide a contribution on intervention in urban watersheds, based on the principles of sustainable development. The study area adopted is the Joana River's Basin, located at the Andaraí, Tijuca, Vila Isabel neighborhoods and at the Maracanã Stadium, which was the object of this pilot project of the Mangue Channel sub-basin (UFRJ, 2002; UERJ, 2002).

It should be emphasized that sustainable development is understood by those ones who seeks to satisfy the needs of the present generation without compromising the ability of future generations when they meet their own needs. Main Topics included in the principal study:

a) Studying the historical evolution of the usage of urban - land in the City of Rio de Janeiro, with emphasis on aspects of pluvial water drainage.

b) Characterizing the physiography including the network of macro - drainage, and land use at the Joana River's Basin.

c) Evaluating the structural flood control measures in the Watershed study, understanding flood control as well as the flow control of the macro-drainage network focused at its containment within the adductor bodies.

d) Analyzing the problem of flooding in the object of the basin study.

e) Presenting and discussing alternatives to the problem studied.

\section{Location of the study area}

The Joana River rises near the Andaraí Highest Point at Grajaú Forest Reserve, about 600 meters above the sea level, west of the Canal do Mangue Basin. Its initial spurt next to south coast, receives pluvial water in the Jacó River and it should be called Joana. Above the confluence with the Jacó River, the basin is almost entirely occupied by dense native forest and scrub vegetation with grasses. 
When the water flow falls on Grajaú, the watercourse becomes an urban gallery covering much disturbed areas, reappearing as an open channel at the confluence of Barão de Mesquita and Maxwell streets, when it receives the flow of Andaraí River at Andaraí neighborhood, coming from the hill and with the same name of the slum. From that point forward, it gets the drainages of the Andaraí, Vila Isabel and some part of Tijuca neighborhoods, like Serra do Engenho Novo, until just before the intersection with the railway line of Rio de Janeiro's trains (SuperVia), near the campus of the Universidade do Estado do Rio de Janeiro (UERJ), which shall be covered. Its outfall is located at the confluence with the Rio Maracanã on the, opposite side of São Cristóvão Subway Station at an elevation of $1.63 \mathrm{~m}$, after flowing for 7.900m (UFRJ,2002,p.58).

The Joana River basin with an area of 1.190 hectares $\left(11.9 \mathrm{~km}^{2}\right)$, is a subbasin of the Mangue Channel basin with a total area of 4.200 hectares $\left(42 \mathrm{~km}^{2}\right)$, as well as other sub-basins of the Maracanã, Trapicheiros and Comprido Rivers. It is partially occupied by the Mata Atlântica (Atlantic Rainforest) and shrub small grasses, usually in the lower part of the coasts. The areas of higher altitudes of the hills were occupied in a disorderly way by low-income communities, causing degradation in the original floristic guards, exacerbated by the carrying of large amounts of waste generated by these communities and dumped at the coasts.

The expansion of cultivation of sugar in the Carioca River Basin region and contributing to the Saco de São Diogo Basin areas, Maracanã, Joana, Trapicheiros and Comprido Rivers were largely responsible for the clearing of forests. In the nineteenth century, the planting of cane sugar was gradually being replaced by coffee in Orange Trees Valley and on the coast of Tijuca, to the Alto da Boa Vista, where British and French population lived in some nobility, in Rio de Janeiro.

The top of the coffee cycle increased deforestation of the hillsides city of Rio de Janeiro. Over time, when transferred into the State, to the borders of São Paulo and Minas States, coffee plantations were largely responsible for the expansion of the occupation of Rio's soil and reactivating its economy.

As for urban interventions in the region, the construction of the port and its operation resulted in large landfills at Baia de Guanabara with the disappearance of 
islands and narrowing the spring of Maracanã, Comprido, Joana and Trapicheiros Rivers, made the Canal do Mangue arise.

The first port of the city on the D. Manuel street, next to the Downtown Forum, even in the colonial period of Brazil, the embankment of the Boqueirão Lagoon, today Public Road, the Sentinel Lagoon and other minors, were the first very striking performances in the city and in the current basin of canal do Mangue.

Other interventions at this basin in the last century were the two terminals of the old Railway Road of Central of Brazil, next to Campo de Santana and the Leopoldina Railway, on the left border of the Canal do Mangue in his last spurt.

These original works fractionated Joana River's basin changing it into the current Joana River's Basin, which together with the Rio Maracanã Waterway, and the Joana River's Basin, with different waterways at the Maracanã and Mangue dumping. Joana River's Basin is part of the Mangue Channel basin, is a sub-basin, in its lower floodplains, resulted in many works that date back over a hundred years, through the modification of swamps, limpets and temporary wetlands on the coast of Baia de Guanabara. These anthropic actions led the profound changes in current flows, both surface and underground systems, notably in the areas of final spurts of urban river runners, this fact that interfered across the macro-basin of the Mangue Channel.

River system in meeting the Catumbi, Papa-Couve, Comprido, Trapicheiros, Maracanã and Joana Rivers, with the final outfalls at the Mangue Channel, mainly flooding began to occur with greater regularity and intensity, heavier and impacting the higher the rainfall and anthropic level of the contributing basins, exutório now centralized in one Guanabara Bay. The meeting dispersed small and medium sized watersheds exutório a single lot was used, as well as allowing the recovery of land was more economical and faster hydraulic deployments, becoming a routine practice.

The occurrence of heavy rainfall and the occupation of areas in the early twentieth century have now become a serious environmental problem and it was getting worse with urban development and also the contribution of occupation of areas around the water basin. 
In the higher areas of the basins the process of 'slumming' began to happen, constituting peripheral belt promoter complex problems: increased erosion and provisions on the plain. With the presence of large masses of scattered garbage, floods have become more massive and energetic generating concentrated water pollution in river flowing.

The excessive level of artificiality of the urban soil on the basin, such as waterproofing, copings, stroke and other hydraulic characteristics imposed at the Mangue Channel, Maracanã and the other sub-tributaries downstream, with densely populated regions, including rail-road terminals, busy road the Leopoldina Railway and Flag Square, became inevitable the strong concentration of flood flows in the main channels mentioned above.

Flooding by rainwater is increasing steadily in urban centers. Every year it comes up with renewed things, causing the destruction of cities, illnesses and people's death. The uncontrolled population growth in urban areas in an expedited way and only in some urban drainage was considered an important factor in planning its expansion. In cities, the increase at impenetrable areas appears generally from low areas near the floodplains of rivers or by the sea, towards the hills and mountains, in the face of interaction required the population to water bodies.

The floods are conditioned climate "natural events", the intense summer rains and characteristics of political negligence. In the natural regime of the river is part of the flow and the variation of quotas, the drought to flood. Floods form when heavy rains fall on the ground already saturated by previous rains without natural absorption capacity. The effects of flooding are attributed largely for necessary human interventions to minimize it depending mainly on increasing the retention of water in the basin and in the lowlands, while reducing the potential losses in the areas of risk, or flood. In urban areas the rivers are treated as if they were isolated compartments, sometimes channeled or rectified, compromising their natural beds and banks, as well as affecting the biological interactions with the Water River areas.

The reversal of this process is difficult. The restoration of rivers and streams in urban areas is only possible where there is space for expansion of their beds, thus improving the problem of disposing of the floods. When there are limited areas 
available, one should look for other possible solutions adapted to the needs of natural evolution, such as the expansion of the riverbed in only one border.

The cost - benefit ratio should be taken into account and be carefully studied, considering the costs to keep the natural long-term evolution, assessing whether they are higher than those for the construction and keeping the conventional waterworks. When the kind of recovery in an urban or rural river decides if it can help of a multidisciplinary team, adding ideas and plan where integrated flood control and ecological recovery solutions are present. There still is not a technical term in water resources engineering for this type of intervention. Revitalization of rivers is, for now, the most used terms.

In Europe, many countries currently in the river areas of flooding have restricted use and are sometimes changes it into recreation area with sports fields, gardens, and even allowing the river bathing, as the issue of water pollution will be resolved.

The process of natural recovery requires knowledge of morphological dynamics of the aquatic ecosystem and especially the understanding and the acceptance of the local population. The recovery of the watercourse must have a plan bound by the following objectives: revitalizing the watercourse; widening the riverbed and providing better conditions for the disposal of floods, ecosystem restoration of the continuity of the watercourse; restoring tracks of water rivers protection and riparian vegetation; creating attractive for leisure-access to water and improved landscape.

The main activities to achieve these objectives, when and where you can apply the techniques of environmental engineering may be: breaking of flow gabions, or rocks and trunks of trees, planting in areas prone to erosion and others, replacing the hydraulic works conventional engineering. In addition, you should perform the removal of obstacles to the flow, while this is new concept in engineering begins to arouse interests in several Brazilian states. However, it certainly will be absorbed in the medium and long term, such as the foreign experience.

Accounting for losses from floods, which are closely linked to factors and interferences attributed to the actions of man are necessary to reassess practices and 
concepts hereby adopted, so that new measures will comprise the cast of action to prevent flooding or mitigate and their losses and deal with it.

Urbanization, population density and property in areas at risk of flooding, along the banks of rivers and lowland regions, will contrast the number and type of actions and its best practices.

Whichever solution adopted by, the key is not to lose the global view of the river basin as the unit electing to participatory management involving the government, organized and productive sectors and specialized academic society.

The actions should be integrated into the local, state and national planning and should be considered the following aspects that will be addressed. The course of the Joana River has a long stretch covered from the junction of the Perdido and Jacó rivers, to Barão de Mesquita Street, at Tijuca neighborhood. In this excerpt, no spots are observed frequent flooding. In the downstream of this gallery, the river follows Joana open channel until crossing the street Pereira Nunes. Along this stretch of flooding points are observed from the intersection of Maxwell Street with Uruguai. The Joan River back to be buffered along a short stretch at Professor Manoel de Abreu Avenue, from Pereira Nunes Street, following again in open channel along this avenue, to the confluence with Maxwell Street and Felipe Camarão Street, where occurs more frequently the spots flood.

The area between the confluence of the Professor Manoel de Abreu and Maxwell Street, to the vicinity of the Célio de Barros stadium at Emílio Garrastazu Medici Square, and Presidente Castelo Branco Avenue is the most critical piece of flooding in covered gallery to its mouth in the Maracanã River.

This section presents important constraints in frequent Joana River basin. From the crossing under the Presidente Castelo Branco Avenue and the railroad tracks, the river follows Joana River flow, causing the damming upstream. The hydraulic study showed that restrictions happen due to the effect of terminating in the backwater of Joan River at Maracanã River, which, during flood events, occurs in fully flooded section. In addition, the gallery in the final stretch of the River Joana, as verified in field inspections, presents interference that cause restriction to flow, such as the crossing of mains pipes. 
Two complementary alternatives in order to reduce the deficit problems at the Joana River basin, and the consequent improvement in the flow at the downstream stretches of the Maracanã River and Canal Mangue were evaluated: the reservation and the amount of deviation from the course of the Joana River directly to Baía de Guanabara.

Throughout the course of Joana River, it was located an area of approximately $6,000 \mathrm{~m}^{2}$ in the parking lot of the Boulevard supermarket, at the time of Engenheiro Otacílio Negrão Avenue. In this area, we evaluated the possibility of installing an offline tank, with the approximate volume of $140,000 \mathrm{~m}^{3}$, which would store the flows from upstream tributary basin, which drainage area is approximately $8.0 \mathrm{~km}^{2}$ and the design flow for $\mathrm{TR}=25$ years is $70 \mathrm{~m}^{3} / \mathrm{s}$. Another area of reservation is located at Alto Grajaú near Furnas sub-station, with a volume of 50,000 cubic meters, which would substitute the river basin Joan downstream.

\section{Deviation of Joan River as an alternative}

The change of the course deviation of Joana River and its dumping at Maracanã River to Baía de Guanabara is an alternative that was evaluated for the first time in 1993, by Mr. Eulálio Antonio Araujo (The Globe, 2010). This would change the function in order to substitute the influx of flows at the end stretch of Joana River, allowing a better use of Maracanã River downstream rail of the spring of Joana, improving the flow in the river downstream of the Maracanã. Since the proposal was first presented, alternative alignments for to get through the problem have been discussed in order to allow better utilization of public money.

In the present study, the tracing analyzed for deviation of Joana seeks to improve the flow from the stretch where the problems begin flooding at the Joana River basin upstream of the crossing of the railway line. The alternative evaluated foresees the implementation of a deviation tunnel was part in the gallery, starting at the height of the intersection of Professor Manuel de Abreu Avenue with Felipe Camarão Street, where the announced top of the spot of flood was observed. The studied route begins at this point, following initially in the gallery, on the stretch crossing the railroad tracks, then it goes back into the tunnel, and finally again in 
gallery along São Cristóvão Street to the point of runoff, at Baía de Guanabara, near the spring, at the Canal do Mangue. The main constructions are the tunnels and galleries. This is the first tunnel for water in Rio de Janeiro.

\section{The deviation works of Joana River}

The deviation of the Maracana River for the Joana River and the deviation of the Joan River to Guanabara Bay will consist of the following works:

\subsection{Gallery Drifting Maracanã River for the Joana River}

This gallery begins and ends at Maracana Avenue in gallery reinforcing channel Joana River, with a length of about 445.00 meters with gallery consists of concrete double section of $3.00 \mathrm{~m}$ by 2.50 each base section $\mathrm{m}$ tall.

\subsection{Gallery of strengthening the channel of Rio Joan}

The gallery reinforcement starts in the pit of input next to Emilio Medici Garrastazu Square and ends at gallery drifting at the time of Felipe Camarão Street. The gallery reinforcement with $584.00 \mathrm{~m}$ gallery consists of concrete double-section of $5.00 \mathrm{~m}$ by $3.00 \mathrm{~m}$ height of each cell.

\subsection{Deviation tunnel of the Joana River}

The deviation tunnel has a total length of approximately 2593.00 me starts after the pit of input gallery strengthening of Joana River and ends in São Cristovão Street, where will be built on a stretch of concrete channel with dimensions of $8.00 \mathrm{~m}$ by $4.00 \mathrm{~m}$ height. After this gallery will run approximately $180.00 \mathrm{~m}$ tunnel to cross the Brazil Avenue and Quayside, local outflow in Guanabara Bay. These tunnels will run with excerpts rock, soil and soil - rock mixed sections.

\subsection{For the NATM Tunnel Method}

Term used to identify the new Austrian tunneling method of execution. The term is defined as NATM method for constructing tunnels in which the mass 
surrounding the tunnel is built to support forming a large loop and therefore part of the supporting structure. In the technical community, the term NATM is commonly used to identify tunnels run by steps covered with shotcrete.

\section{Diagnostic Program History}

In the intervention area for the passage of works from the railroad tracks, with significant depths underground excavations, and because this area is built into the group of possible areas containing archaeological remains, it is necessary to work consultations with surveys bibliographic and graphics documents available in preservation agencies, as well as visits and surveys throughout its stroke, in order to legalize research, with all material found on IPHAN there, according to the regulations.

Here hydraulic interventions Basin Canal do Mangue, aiming at Charter Consulting works of reservation in the basins of rivers Trapicheiros and Joan, in order to reduce the risk of flooding in the basin.

This part is linked to the Diversion Joana River, although distinct works. Hydrological studies considering the condition of the integrated operation of the watershed system and their operation optimized for the following interventions:

- RJ - 1 Reservoir (Joana River);

- RJ - 3 Reservoir (Joana River);

- RT - 1 Reservoir (Trapicheiros River);

- RT - 2 Reservoir (Trapicheiros River).

- Deviation of the Joana River;

- Derivation of flow of the Rio Maracanã for the Joan River;

- Reinforcement gallery in Rio Joan.

\section{CONCLUSIONS AND RECOMMENDATIONS}

Given the above it is concluded that the state has a leading role in sustainability, however the environmental practices in Brazil will curb the sense of the impacts on the environment when they have occurred, using legal means, 
monitoring and repressing often so ineffective. Environmental aspects are not integrated in the formulation and implementation of sectoral and macroeconomic policies. The rulers and decision makers ultimately act in immediate form, exacerbating the resulting economic and social situation of lack of planning to consider these aspects.

The urban centers of the State of Rio de Janeiro grow spontaneously, meeting the immediate needs of the low income population, which for lack of adequate housing conditions and without funding sources, seek own solutions inhabiting the most unhealthy places and risk as the slopes and marginal bands of rivers and lowlands.

The study highlighted the problem that has been plaguing the region for a long time, i.e., floods, responsible for major disasters and losses were exacerbated by urbanization has led to degradation of natural ecosystems own existing topography that is constituted mainly of remnants Atlantic Forest on the slopes and in areas of mangroves downloaded .

In studies contracted by Fundação Rio-Águas, not all proposals by PDMAP (Master Plan for Management Rainwater) interventions were implemented up to now. Drainage measures correspond to a sizable step and cause major disruptions in its implementation, especially in parts where there slums. It is emphasized that any work to improve these areas is well accepted by the local population because it feels valued.

For purposes of further studies, it is recommended to follow the evolution of anthropogenic processes for the study area and seek greater depth of knowledge of government interventions that occurred in the area, which was not possible in the scope of this work.

\section{Keywords}

Water Resources Management; Watershed Handling; Method for Planning and Flooding Control; Hydrology, Water, Urbanism; Urban Development Urban and Environmental Engineering; Sustainability. 


\section{Sumário}

1. Introdução 22

1.1. Objetivo do estudo 23

1.1.1. Geral 23

1.1.2. Específicos 24

2. Revisão de literatura 25

2.1. Urbanismo e cidade 25

2.2. A evolução urbana do Rio de Janeiro 33

2.3. A ocupação urbana na bacia do Canal do Mangue 39

2.4. A ocupação urbana na bacia do Rio Joana 41

2.5. As enchentes nas bacias hidrográficas urbanas 44

3. Localização da área de estudo 52

3.1. Caracterização física da bacia 52

4. Ações para mitigação do efeito das enchentes 54

5. Análise da problemática das enchentes na bacia hidrográfica do Rio Joana e alternativas para minimizá-las 57

5.1. Alternativas de intervenção na bacia do Rio Joana 60

6. Detalhamento do projeto: Obras de desvio do Rio Joana com Execução de galerias, reforço de calha e intervenções complementares visando ao controle de enchentes da bacia do Canal do Mangue -. Praça da Bandeira 63

6.1. Descrição das obras 63

6.1.1. Galeria de derivação do Rio Maracanã para o Rio Joana 63

6.1.2. Galeria de Reforço do Canal do Rio Joana 63 
6.1.3. Túnel de desvio do Rio Joana

64

6.1.4. Túnel pelo método NATM (New Austrian Tunneling Method) 64

6.1.5. Programa de diagnóstico histórico 64

6.2. Estudo de alternativas para a redução do risco de inundações na Bacia hidrográfica do Canal do Mangue 65

6.2.1. Alternativas de intervenção na bacia do Rio Maracanã 66

6.2.2. Alternativas de intervenção na bacia do Rio Trapicheiros 68

6.3. Esquema hidráulico do sistema proposto 69

6.3.1. Desvio do Rio Joana 69

6.3.2. Derivação de vazões do Rio Maracanã para o Rio Joana 70

7. Conclusões e recomendações 79

$\begin{array}{ll}\text { Referências Bibliográfica } & 81\end{array}$ 


\section{Lista de figuras}

Figura 1 - Enchente da Praça da Bandeira em $1940 \quad 46$

Figura 2 - Enchente no Canal do Mangue em $1942 \quad 47$

Figura 3 - Rio Joana - Abril de $2010 \quad 49$

Figura 4 - Rio Joana - Abril de $2010 \quad 50$

Figura 5 - Enchente da Praça da Bandeira em Abril de 2011

Figura 6 - Enchente da Praça da Bandeira em Abril de 2011

Figura 7 - Rio Joana - Abril de 2011

Figura 8 - Planta de situação da Bacia do Rio Joana 53

$\begin{array}{ll}\text { Figura } 9 \text { - Visão geral do projeto } & 71\end{array}$

Figura 10 - Transferência de vazão do Rio Maracanã para o Rio Joana Num total de $40 \mathrm{~m}^{3} / \mathrm{s} \quad 71$

Figura 11 - Galeria de reforço Joana - Av. Prof. Manuel de Abreu 72

Figura 12 - Galeria Existente x Galeria Projetada 72

Figura 13 - Diagrama Unifilar do Projeto 73

Figura 14 - Galeria Existente x Galeria Projetada x Poço C 74

$\begin{array}{ll}\text { Figura } 15 \text { - Poços B e C } & 75\end{array}$

Figura 16 - Túnel Subterrâneo (Extensão de 2.400m) 76

Figura 17 - Planta Baixa - Trecho em Túnel 76

Figura 18 - Seção do Túnel $\quad 77$

Figura 19 - Vista Frontal do Emboque do Poço $\quad 77$

Figura 20 - Rua São Cristóvão - Trecho em galeria aberta e fechada 78

Figura 21 - Planta Baixa - Rua São Cristóvão 78

\section{Lista de tabelas}

Tabela 1 - Ações para mitigação dos efeitos das enchentes em Bacias Hidrográficas 


\section{Lista de Abreviaturas}

Av. - Avenida

Eng. - Engenheiro

IPHAN - Instituto do Patrimônio Histórico e Artístico Nacional

NATM - New Austrian Tunneling Method

PUC Rio - Pontifícia Universidade Católica do Rio de Janeiro

Prof. - Professor

Pres. - Presidente

TR - Tempo de Recorrência

UERJ - Universidade do Estado do Rio de Janeiro

UFRJ - Universidade Federal do Rio de |Janeiro

UNFPA - United Nations Population Fund

SuperVia - SuperVia Trens Urbanos 
"Há homens que lutam um dia e são bons. Há outros que lutam um ano e são melhores. Há os que lutam muitos anos $e$ são muito bons. Mas há os que lutam a vida inteiro, esses são os imprescindiveis".

Bertold Brecht. 


\section{Introdução}

A ocupação desordenada nas grandes metrópoles tem levado a antropização dos recursos ambientais das bacias hidrográficas e, consequentemente, graves problemas são observados, sobretudo nas épocas de maior pluviosidade.

A ocupação sem planejamento nas bacias hidrográficas urbanas tem causado sérios impactos ambientais, tais como: enchentes, deslizamentos de terras, desmatamentos, erosões, assoreamentos, resíduos sólidos e líquidos, falta de água para abastecimento, problemas de saúde pública devido à carência de saneamento básico, especialmente nas comunidades de baixa renda localizadas nas encostas de morros e nas periferias urbanas. A densidade demográfica elevada em regiões de difícil acesso torna precária a execução e manutenção do saneamento básico pela dificuldade de acesso.

A coleta de lixo é outro problema sério, tornando essas regiões impróprias para moradia. O lixo disperso lançado nos cursos d'água aumenta os riscos de inundações à jusante da bacia.

Como forma de mitigar tais problemas é que se propõe o planejamento ambiental. Odum (1985, p.34), afirma que:

\footnotetext{
"é consenso mundial que a bacia hidrográfica é a unidade territorial para se promover à gestão do meio ambiente, pois, entre outros aspectos, suas fronteiras (divisores de água) são naturais e na maioria das vezes percebidas com facilidade" (...). "A bacia hidrográfica (...) deve ser considerada a unidade mínima de ecossistema, quando se trata de interesses humanos (...e) ajuda a colocar em perspectiva muitos dos nossos problemas e conflitos. Por exemplo, as causas e as soluções da poluição da água não serão encontradas olhando-se apenas para dentro da água; geralmente, é o gerenciamento incorreto da bacia hidrográfica que destrói nossos recursos aquáticos"
}

Nas últimas décadas os mananciais originais estão cada vez mais poluídos e exauridos, afetando não só a quantidade, mas também a qualidade da água de abastecimento público. O solo fértil natural em todo o mundo está escasseando, mesmo com o aumento da demanda da produção de alimentos, a vegetação nativa é 
cada vez mais escassa. Tais processos resultam na redução da biodiversidade ecológica, agravados por alterações climáticas e na qualidade do ar.

As enchentes e secas cada vez mais intensas vêm ocorrendo nas bacias hidrográficas antropizadas, gerando problemas de calamidade pública. Este processo pode ser observado durante a ocupação do Rio de Janeiro quando:

"desviamos os cursos naturais dos rios, aterramos áreas importantes de acumulação de águas, desmatamos encostas que ajudavam a refrear as águas e impermeabilizamos o solo" (REVISTA RIO-ÁGUAS, 1999, pág. 4).

Por outro lado,

"os grandes aglomerados urbanos geraram um impacto no espaço natural. Dentro dessa área impactada, formou-se um ecossistema urbano próprio, onde o homem se destaca pelo grau elevado de interferência nos processos naturais” (Idem, pág. 14).

Cabe salientar que a pesquisa envolve o desvio do Rio Joana e a implantação dos reservatórios de amortecimento das cheias. Embora sejam duas obras separadas, uma contribui para a outra.

\section{1}

\section{Objetivo do Estudo}

\subsection{1 \\ Geral}

A presente pesquisa busca fornecer uma contribuição para as intervenções em bacias hidrográficas urbanas, baseada nos princípios do desenvolvimento sustentável. A área de estudo adotada é a Bacia do Rio Joana, localizada nos bairros do Andaraí, Tijuca, Vila Isabel e Maracanã, que foi objeto de projeto piloto nesta sub-bacia do Canal do Mangue (UFRJ, 2002; UERJ, 2002).

Cabe salientar que se entende por desenvolvimento sustentável aquele que busca satisfazer as necessidades da geração atual, sem comprometer a capacidade das gerações futuras de satisfazerem as suas próprias necessidades. 


\subsection{2}

\section{Específicos}

a) Estudar a evolução histórico-urbanística da ocupação do solo na Cidade do Rio de Janeiro, com ênfase nos aspectos de drenagem pluvial.

b) Caracterizar a fisiografia, incluindo a rede de macro-drenagem e o uso da terra na Bacia Hidrográfica do Rio Joana.

c) Avaliar as ações estruturais de controle de inundações na Bacia Hidrográfica em estudo, entendendo o controle de inundações como o disciplinamento dos escoamentos da rede de macro-drenagem.

d) Analisar a problemática das enchentes na Bacia Hidrográfica objeto do estudo.

e) Apresentar e discutir as alternativas ao problema estudado. 


\section{2}

\section{Revisão de literatura}

\section{1}

\section{Urbanismo e cidade}

A cidade é tida como o principal objeto de estudo do Urbanismo (o que revela um dualismo), sendo muito mais do que uma aglomeração de pessoas e construções num determinado espaço territorial. É o lugar para onde converge o fluxo de capital econômico, social, financeiro, advindo de várias localidades que estabelecem com ela relações sociais, políticas e econômicas, e enfim, onde se concentram os bens de reprodução do capital e a força de trabalho. Isto demonstra a complexidade do que é a cidade. $\mathrm{Na}$ cidade acontecem intensas relações sociais de troca, de movimento, de poder e por isso é dinâmica. Seus espaços são dinâmicos e se transformam no decorrer do tempo em virtude de todos estes e outros fatores.

Observou-se então nos últimos anos um crescimento surpreendente das cidades, em tamanho, população e densidade, o que trouxe para ela a concentração dos problemas que afligem a humanidade, desafiando a sociedade.

A sociedade em que vivemos tornou-se essencialmente urbana a partir do período do final do séc. XIX, pós-revolução industrial, e assim os problemas urbanos começaram a se acentuar, diante do aumento da população nas cidades decorrente do êxodo rural, em busca de oportunidades de trabalho e sem condições dignas de qualidade de vida. A partir daí várias cidades cresceram em tamanho e população e se transformaram em metrópoles, extrapolando seus limites territoriais formando conurbações (várias cidades inter-relacionadas num tecido urbano contínuo). Então surgem propostas na tentativa de buscar soluções para estes problemas, com uma pretensão científica, e também se criam modelos de desenvolvimento urbano para as cidades, muitos deles utópicos a fim de se organizar os espaços da cidade, os seus territórios, suas diversas atividades. Neste contexto é que surge o Urbanismo. 
A partir do séc. XIX surgiram vários modelos de desenvolvimento urbano, em busca de solução para os problemas decorrentes do grande processo de urbanização das cidades europeias, na tentativa de se criar a cidade ideal, tidos como teorias, que se tornaram utópicas, a exemplo das ideias de Fourier, com o falanstério, de Howard que idealizava a Cidade-jardim, e de Tony Garnier, com a teoria da cidade industrial (CHOAY,1965).

Naquela época, grandes cidades como Londres e Paris, apresentavam crescimento populacional bastante acelerado, no período da Revolução Industrial, quando grandes contingentes populacionais migravam do campo para a cidade em busca de trabalho, e então se criaram grandes aglomerados populacionais nos quais as pessoas que pertenciam à classe operária viviam em péssimas condições de vida, principalmente de higiene, muitas delas sem ter onde morar, ou habitando em locais insalubres e desconfortáveis. Houve então a partir daí uma grande discussão em diversas áreas do conhecimento na busca por soluções para estes chamados "problemas urbanos". Naquela época, da revolução industrial, dos movimentos sociais e dos racionalismos que emergiam ainda não se tinha um conceito de Urbanismo aprimorado, e nem o mesmo era considerado como uma área do conhecimento ou ciência de organização dos espaços urbanos, o que só acontece alguns anos depois, no início do séc. XX (CHOAY, 1965).

A observação e a reflexão sobre os problemas da cidade assumem ainda no século XIX, outras vertentes de pensamento. Uma delas seria descritiva, observando os fatos isoladamente, ordenando-os de maneira quantitativa, coma aplicação da Estatística à Sociologia, então nascente, a fim de formular teorias de crescimento da cidade. Outra seria constituída por pensadores políticos e traria a polemização sobre os problemas de higiene e das grandes cidades industriais europeias e norte americanas, assim como a habitação da população oriunda das classes sociais menos favorecidas. Alguns destes pensadores como Marx e Engels analisaram estes problemas dentro de uma lógica referente à ordem econômica e social para a organização do espaço urbano promovida pela industrialização não associada à lógica do desenvolvimento da economia, mas para a produção e comercialização em larga escala e a concentração do capital gerado nas classes dominantes. 
O território da cidade é formado pelos fluxos de mercadorias e pessoas, sendo ela (a cidade) a configuração da estrutura social, e a materialização desta estrutura no território. As transformações no espaço urbano são fruto não só das relações intraurbanas, mas de ralações regionais e globais, já que a cidade não é um lugar fechado em si, ela assume relações que ultrapassam a esfera local e regional, e isto exige que se tenha uma visão da cidade inserida num contexto político-econômico mais abrangente.

A cidade ideal se apresenta como fruto dos valores éticos, filosóficos e sociológicos de cada cultura e de cada época. As teorias da cidade evoluem e enriquecem, por isso é difícil saber como é a cidade ideal, já que algum tempo depois da sua definição ela já não vai corresponder às expectativas da época. Assim, o Urbanismo não pode ser observado apenas sob o ponto de vista de uma técnica de estudo e intervenção física do espaço, pois quando de intervém na sua morfologia, ele necessita ser estudado e planejado conhecendo os aspectos sociológicos, filosóficos, históricos, etc. e sendo que uma cidade é resultado das diversas mudanças que ocorrem na sociedade, e que lhe impõe transformações (BONET CORREA, 1989).

Há de se entender, entretanto, que o conjunto de ações de intervenção no espaço urbano historicamente muitas vezes está voltado para a dominação e de poder político pelas elites, causando a segregação sócio-espacial. Assim o estudo do Urbanismo merece uma abordagem crítica enquanto ciência, área de conhecimento ou instrumento de intervenção no espaço urbano, voltando-se principalmente para como o seu conceito é entendido no Brasil e outros países, pois se trata de uma ciência ou campo do conhecimento de grande complexidade.

De acordo com Santos (1993), tanto o crescimento da economia industrial como o estilo de vida urbano criou uma densa rede urbana, composta por nove regiões metropolitanas: Belém, Fortaleza, Recife, Salvador, Belo Horizonte, Rio de Janeiro, São Paulo, Curitiba e Porto Alegre. Tais regiões foram criadas por lei visando atender a critérios certamente válidos de um ponto de vista oficial, à época de sua fundação. Atualmente a eles se podem acrescentar outras "regiões urbanas" que mereceriam idêntica nomenclatura. 
O fenômeno de metropolização é mais dinâmico do que a legislação. Isso pode ser dito também sobre as práticas de planejamento urbano. De uma forma geral essas regiões metropolitanas se desenvolvem com maior velocidade do que o ato de planejar o espaço, o que gera um crescimento desordenado, implicando em impactos sociais e ambientais.

Maricato (2001) salienta que essa urbanização sem planejamento criou uma situação caótica nas principais capitais do país e suas regiões metropolitanas, ocasionando um crescimento na pobreza e consequentemente na violência. $\mathrm{O}$ processo de modernização da economia brasileira até os dias de hoje, não levou à superação da pobreza e das desigualdades sociais, a modernização aprofundou as desigualdades já existentes geradas num passado distante, pois esteve apoiada numa maior concentração de renda. Apesar da expansão das camadas médias, que apresentam um bom poder aquisitivo e contribuíram para a expansão do mercado consumidor, a diferença de rendimentos entre ricos e pobres é hoje muito maior do que no início da modernização. Dessa forma se desenvolvem a trama, ou talvez o drama da urbanização nos países periféricos, um processos muito acelerado que ocorre sem que as condições mínimas necessários para o seu desenvolvimento seja respeitado, como infraestrutura e planejamento, o que implica em consequências graves.

Para Mota (1999) o crescimento da infraestrutura urbana deveria acompanhar o crescimento da população e a ampliação das cidades, proporcionando, dessa forma uma mínima condição de vida à população, entretanto, não é isso que ocorre.

O autor salienta ainda que é de suma importância que haja uma ordenação desse crescimento, propiciando um equilíbrio entre este o meio ambiente. $\mathrm{Na}$ verdade, a realidade do processo de urbanização difere muito do que enquadra como ideal. Isso ocorre devido à falta de um planejamento urbano adequado o que acaba gerando um crescimento de forma desordenado, com uma falta de infraestrutura capaz de propiciar uma qualidade ambiental aceitável.

De acordo com Silva (1998) a ocupação desordenada propicia vários problemas, uma vez que, além de deteriorar o ambiente urbano, provoca a 
desorganização social através da carência de habitação, desemprego, problemas de higiene e de saneamento básico. Além disso, acaba modificando a utilização do solo e transformando a paisagem urbana. A solução desses problemas obtém-se pela intervenção do poder público, que procura transformar o meio ambiente e criar novas formas urbanas.

Segundo Branco e Rocha (apud Mota, 1999) a perspectiva é de que o planejamento urbano seja utilizado de forma integrada em termos ecológicos, físicoterritoriais, econômicos, sociais, administrativos, abrangendo as partes, os elementos e o todo de um sistema ou ecossistema. Tal concepção de planejamento está associada à ideia de desenvolvimento sustentável.

Para Mota (1999), o planejamento urbano deve ter como base a concepção de desenvolvimento sustentável, ou seja, aquele que atende às necessidades do presente sem comprometer o futuro. Para que haja um planejamento urbano de forma integrada é preciso agir visando à preservação ambiental, pois é mais correto evitar os males gerados pela urbanização ao invés de ter que corrigi-los posteriormente. Com isso, entende-se a necessidade de considerar as questões ambientais na tomada de decisões relativas ao planejamento urbano.

Em 2008, mais da metade da população do planeta, ou seja, 3,3 bilhões de pessoas vivia no meio urbano. Tal fato, que o Fundo das Nações Unidas para a População (UNFPA) qualifica como um ponto de inflexão extremamente importante na história da humanidade vem acompanhado, em seu relatório anual, de um prognóstico preocupante: até 2030 a previsão é que a população urbana mundial alcance os 5,0 bilhões de pessoas (UNFPA, 2007).

Segundo Davis (2007), o problema reside no fato do crescimento da população urbana previsto para a humanidade ser absorvido em sua maioria pelas cidades dos países em desenvolvimento, geralmente dotadas de pouca ou praticamente nenhuma estrutura, dependendo da área, para fornecer adequadamente habitação e serviços básicos à vida. Pelas estimativas do UNFPA, essas cidades abrigarão, até 2030, 81\% da população urbana mundial. 
Maricato (2001) salienta ainda que o que ocorre, então, é que com esse crescimento populacional urbano sem precedentes, as pessoas vão habitar os assentamentos informais precários ao redor do mundo, sujeitos ao despejo, à violência das forças políticas de plantão, às políticas públicas baseadas no clientelismo, quando for do interesse dos grupos dominantes da sociedade local ou global, dependendo do caso.

Segundo Davis (2007) a partir de 1970, o crescimento das favelas acabou ultrapassando a urbanização propriamente dita e transformou a chamada "urbanização" em um retrato da pobreza de forma diferente da que se verifica em países desenvolvidos, onde as cidades se expandiram não devido à pobreza, mas sim pela demanda de mão de obra na atividade industrial.

De acordo com Castro e Silva (1997), o indicador que expressa de forma sintética a crítica dimensão atingida pelos problemas urbanos, em especial metropolitanos, no Brasil, é a gigantesca ilegalidade presente na ocupação do solo a partir das terras invadidas ou parceladas irregularmente. Esse fenômeno nos permite afirmar que a exceção passou ser regra e a regra exceção.

Simões (2000) afirma que ele não se restringe a uma questão formal - ser legal ou não -, pois implica muitos aspectos negativos que acompanham o crescimento urbano, como a ocupação de áreas ambientalmente frágeis, como beiras de rios, de córregos, de lagoas, mangues, reservatórios de água potável, dunas, áreas de matas e florestas, encostas instáveis e várzeas.

De acordo com Maricato (2001), o desenvolvimento metropolitano veio acompanhado de problemas sociais e ambientais, tais como a falta de moradias e favelização, a carência de infraestrutura urbana, o crescimento da economia informal, a poluição, a intensificação do trânsito, a periferização da população pobre, a ocupação de áreas de mananciais da planície de inundação dos rios, e de vertentes de declive acentuado.

Para Davis (2007), a favela é um tecido urbano superpopuloso, que apresenta via de regra, um conjunto de situações e problemas como habitações informais muito pobres, acesso inadequado à água, ao saneamento, à eletricidade, à coleta de resíduos 
e à segurança, entre outros parâmetros. $\mathrm{O}$ autor afirma que os favelados constituem surpreendentes $78,2 \%$ da população urbana nos países menos desenvolvidos e um terço da população urbana total.

$\mathrm{O}$ autor menciona ainda que, pelo menos a metade dos seus moradores tem menos de vinte anos de idade. O Brasil figura em terceiro lugar em número absoluto de favelados, somando uma população de mais de 51,7 milhões de favelados, numa taxa percentual de $36,6 \%$ dos brasileiros.

Para Maricato (2001), a desigualdade urbanística é evidenciada pela segregação territorial. Nesse caso, a autora se refere à apropriação social diferenciada da cidade, seus edifícios com diversos usos, clubes, equipamentos de lazer e cultura, ruas, calçadas e mobiliário urbano. Não é correto, embora seja frequente separar aspectos sociais, econômicos jurídicos e culturais dos aspectos urbanísticos e ambientais. A desigualdade social e econômica (renda, escolaridade, desemprego, violência) tem maior reconhecimento, na sociedade brasileira do início do século XXI, do que a desigualdade urbanística (condições de moradia, saneamento, transporte, por exemplo). Mesmo a agressão ambiental apenas muito recentemente e de modo ainda incipiente passa a ser relacionada com a pobreza urbana.

Maricato (2001) acentua que são duas as principais consequências da segregação territorial: a predação ambiental que é promovida pela dinâmica de exclusão habitacional e assentamentos espontâneos; e a escalada da violência, que pode ser medida pelo número de homicídios e que se mostra mais intensa nas áreas marcadas pela pobreza homogênea, isto é, nas grandes cidades.

Para Maricato (2001), a segregação nas cidades e regiões metropolitanas, merece uma reflexão capaz de agregar as características de uma democracia inclusiva, ou seja, superar a mera representatividade muitas vezes cínica, incorporar o "mosaico" urbano sócio, econômico e ambiental, com o desafio de construir outras relações, superando os debates técnicos de desenhos sem lugar, sem cara, sem população, construindo outros lugares, capazes de promover a identidade local, discutir o que é efetivamente essencial para a qualidade de vida dos cidadãos e para a sobrevivência dos ecossistemas onde vivem, reinventando a própria cidadania. 
Santos (2005) sugere a realização de um pacto multicultural no fantástico mosaico urbano. Um pacto que tem no centro do foco a sustentabilidade humana nas cidades, traduzida na qualidade de vida e na inclusão sócio-urbana-ambiental, para todos.

Maricato (2001) salienta ainda que a consciência da inter-relação entre esses fatores ainda é muito restrita embora a falta de alternativas de moradia via mercado privado ou via promoção pública seja a maior causa da agressão aos mananciais de água que se localizam nos arredores de grandes e medias cidades.

Segundo Souza (2008), apesar do país ter em 2002, 82\% da população nas cidades e $30 \%$ apenas em nove metrópoles a falta de política metropolitana, urbana e habitacional não constitui motivo para indignação de muitos. $\mathrm{O}$ fato das cidades de porte médio começar a apresentar favelas ou ambientes pobres e segregados é reconhecido como problema não decorrente da existência desses "guetos" em si, mas principalmente devido à luta que parte do Estado brasileiro trava (quando o faz, quando não desiste) com a criminalidade que avança celeremente sobre o território "liberando" áreas do contrato social que regula nossa sociedade para implantar regras específicas de convivência. A cidade ilegal que começa a superar em números a cidade legal, em várias capitais, é muito desconhecida. Melhor seria dizer que ela é oculta.

A evolução das favelas no Brasil pode ajudar a elucidar alguns aspectos da questão. Ela acompanhou o processo de urbanização da sociedade, que se deu, praticamente, no século XX. Ela é determinada pelo modo como se deu a industrialização e a reprodução dos trabalhadores, a partir da emergência do trabalho livre. Na sociedade escravocrata, a moradia do trabalhador era provida pelo patrão, bem como os demais itens de sua subsistência. Os trabalhadores brancos livres gozavam de uma condição ambígua, num modo de produção marcado pelo trabalho compulsório e visto como coisa degradante. A política do favor marcou o modo de vida desse trabalhador branco, que vivia à sombra dos chamados coronéis, latifundiários. 


\section{2}

\section{A evolução urbana do Rio de Janeiro}

A discussão se inicia com a apresentação das características gerais do Rio de Janeiro, da parte geográfica e demográfica, dando um panorama da situação da cidade no período de transição entre o modelo colonial e capitalista.

O Rio de Janeiro colonial era uma cidade portuária nas margens da baía de Guanabara, espremida entre os morros, ocupando um espaço conquistado através do dessecamento dos brejos e manguezais da região. Durante o século XIX, ocorreram inúmeras modificações a nível político e econômico, com influências na estrutura social e na configuração do espaço urbano, a começar pela vinda da família real portuguesa, em 1808, que trouxe para a colônia uma classe até então inexistente e novas necessidades materiais (ABREU, 1987).

Segundo Lessa (2000), o Rio Imperial, era sujo e enfermiço, tinha poucas facilidades urbanas, falta de rede de esgotos, falta d'água, infecções por doenças, pouca prosperidade para o crescimento individual. Abreu (1987) diz que os habitantes do centro estavam tão próximos em suas relações, que isso se refletia no modo como os imóveis eram construídos: muitos prédios eram erguidos um ao lado do outro, para facilitar a comunicação entre os diversos setores do comércio local. Tal situação veio a desencadear um problema no Rio de Janeiro: a questão da moradia popular, que se desenvolvia na forma dos grandes cortiços na cidade. Um espaço que, na era colonial, era quisto pela elite e que foi ainda mais desenvolvido nesse sentido, com a chegada da família real e com o desenvolvimento demográfico.

Depois da independência, em 1822, a capital transformou-se em polo de atração de trabalhadores livres, nacionais e estrangeiros, trazendo uma nova conformação social e novos problemas na organização da cidade.

Do ponto de vista do espaço urbano, a cidade tinha ainda características coloniais. Dividia-se em cinco freguesias centrais, que abrangiam a área do porto, o largo do Paço - com a sede do governo imperial - e as áreas comerciais e financeiras. Nestes mesmos locais encontravam-se tanto as habitações populares quanto as moradias das classes dirigentes, sendo que estas, pelo seu poder de mobilidade, 
também tinham como opção as chácaras na zona sul (Glória e Catete), subúrbios que levavam ao caminho de Botafogo, na zona rural (BENCHIMOL, 1990).

O centro populoso abrigava um conjunto heterogêneo de escritórios, lojas, bancos, depósitos, oficinas, trapiches, prédios públicos, armazéns (quase sempre com cortiços ou estalagens construídos nos fundos, funcionando como fonte de renda complementar), sobrados e casas térreas, que eram habitações particulares, e casarões transformados em casas de cômodos, servindo de moradia para as populações de baixa renda.

O velho arraial de São Cristóvão, na zona norte da cidade, teve o privilégio de abrigar a residência da família real, o que levou à melhoria dos caminhos de acesso e ao aterro de uma parte do Saco de São Diogo. Estas obras permitiram maior salubridade e aproximou a região do centro, o que levou à formação da chamada Cidade Nova. Em volta do palácio de São Cristóvão passaram a se instalar as residências da aristocracia, que tinha poder de mobilidade, transformando o velho arraial em elegante bairro, com a rápida multiplicação de moradias ricas. Para essa região dirigiram-se as primeiras diligências, e também os pequenos ônibus de tração animal, chamados "gôndolas".

Segundo Abreu (1987), só a partir do século XIX é que a cidade do Rio de Janeiro começa a transformar radicalmente a sua força urbana e a apresentar verdadeiramente uma estrutura espacial estratificada em termos de classes social. No texto Mauricio informa o seguinte a respeito dessa transformação: "A vinda da família real impõe ao Rio uma classe social até praticamente não existente.”.

Nessa fase a Europa vive mudanças profundas face às revoluções burguesas. As ideias liberais vêm chegando ao Brasil, mas segundo Dias (2005), a mecânica é diferente. Aqui o modelo não é capitalista aos moldes liberais, é escravista, devido ao modo de produção ser diferente. Na Inglaterra o camponês sai do campo para trabalhar na indústria. A França se destaca pelas invenções. No Brasil a mão de obra é outra, como bem explica Carlos Soares, "quase todos os ramos da atividade industrial, os trabalhadores escravos desenvolviam as mesmas tarefas que os trabalhadores livres...". Apesar do surto no Rio de Janeiro, de crescimento industrial, 
em 1840, o processo era bem diferente do que ocorria no auge da revolução industrial na Inglaterra, 1830/1840.

De acordo com Lessa (2000) a urbanização do Rio de Janeiro enquadra-se no mundo da revolução industrial, porém sem industrialização, não constituindo o assalariado característico do capitalismo industrial: não havia proletariado da forma que ocorreu na Inglaterra.

No velho centro fervilhava uma multidão heterogênea que nele habitava e trabalhava, através de diversas formas de sobrevivência dentro de reduzido espaço urbano. Aí se misturavam escravos de ganho e trabalhadores livres, vendendo sua força de trabalho, ou produtos variados como comidas e objetos reciclados, enfim, qualquer atividade por uma diária. A partir dos anos 1850, intensificou-se a entrada de capitais estrangeiros, aplicados principalmente em serviços públicos. A sociedade tradicional, apoiada em relações escravistas de produção, começou a adquirir novos hábitos e necessidades essencialmente capitalistas, em particular a partir do crescimento do café como principal produto de exportação. Esse processo só fez acentuar as contradições da cidade, movida por duas lógicas distintas, escravista e capitalista (ABREU, 1987).

No último quartil do século XIX, o Rio de Janeiro passou a ser o principal centro comercial e financeiro do país. Durante a década de 1880 , intensificou-se o estabelecimento de indústrias, principalmente têxteis, nos arrabaldes distantes do centro, como Laranjeiras, Botafogo, Jardim Botânico, Gávea, Tijuca e Andaraí. No velho centro e na chamada Cidade Nova, que se expandia no caminho de São Cristóvão, cresceu o número de pequenas oficinas de artesanato e manufaturas, sobretudo depois da proclamação da República.

Na década de 1890, São Cristóvão perdeu definitivamente seu prestígio com a transferência das famílias abastadas para a zona sul e a adaptação dos antigos solares em espaços de produção fabril ou casas de moradia coletiva. A região transformou-se em densa zona industrial. O Rio de Janeiro crescia em ritmo vertiginoso, em função das levas de imigrantes e do êxodo rural, sobretudo depois da abolição da escravatura, em 1888. Entre 1872 e 1890, a população urbana praticamente dobrou, passando de 
274.972 a 522.651 habitantes, que correspondeu a um aumento de $90 \%$ em dezoito anos. Dez anos depois, a cidade já tinha 691.565 habitantes, e em 1906 atingia 811.444. Era a única cidade no país com mais de 500 mil habitantes, sendo que as duas outras principais cidades, São Paulo e Salvador, tinham na época pouco mais de 200 mil (BENCHIMOL, 1990).

O crescimento populacional dos anos 1880 correspondeu principalmente a uma entrada de população rural, vinda das fazendas de café da Província do Rio de Janeiro, que começavam a perder a produtividade, até o êxodo em massa nos últimos anos da década, com o final da escravidão. Essas levas de migrantes ex-escravos, basicamente trabalhadores rurais, de certa forma rebelde à disciplina pela própria reação a um processo que os desqualificava, transformaram o velho centro do Rio num gigantesco mercado de trabalho informal, em que cada um vendia sua força ou sua inventiva para sobreviver (BENCHIMOL, 1990).

O Rio de Janeiro de forma geral teve que se relacionar com duas realidades distintas: a convivência como o escravismo e nova tendência liberal capitalista do século XIX. Mas, o Rio de Janeiro "teoricamente" não atendia as normas, tendências inovadoras, que o período moderno exigia das grandes cidades mundiais. O Rio para se adequar às novas necessidades, teve que reformular os seus padrões, tanto na arquitetura quanto na representação social de suas elites. E é em torno dessa questão que é desenvolvido trabalho de analise do autor. Segundo ele a parte principal da cidade foi desenvolvida submetida às causas naturais da geografia. Era um tanto difícil se pensar em uma expansão urbana quando as causas naturais não contribuíam para tal feito de crescimento em outros territórios que não os iniciais no centro da cidade do Rio de Janeiro. A área era um tanto pantanosa, o que dificultava o desenvolvimento imobiliário, a princípio. E, levando em conta toda essa situação, o núcleo comercial se resumia às áreas do centro, não havendo sentido para o crescimento urbano para além desses limites. Somente com a chegada da família imperial é que essa situação tende a mudar por inúmeras razões.

Após o fỉm da escravidão a situação muda radicalmente. Consequentemente, a massa populacional aumenta consideravelmente, o que leva, até certo ponto, à 
degradação e à saturação desses espaços que, em alguns casos, não contavam com nenhuma política pública voltada para a saúde. Os espaços do centro eram disputados entre negros de ganho e trabalhadores livres, o que veio a se tornar uma realidade mais intensa com o fim da escravidão.

Após a incursão de escravos libertos e trabalhadores pobres, o espaço urbano passa a ser relegado a relações capitalistas, o que resultou numa necessidade de suporte para essa estrutura: a proximidade de áreas urbanas que abrigavam contingentes de trabalhadores que se deslocavam para o centro. Essa realidade faz com que a elite busque outros lugares menos disputados e dissociados das relações capitalistas diretas. Os setores públicos são "forçados" a desenvolverem projetos públicos para desafogar e dar novo aspecto ao centro. O que levou às obras de escoamento de áreas pantanosas que foram destinadas aos novos empreendimentos imobiliários. À medida que o Centro do Rio de Janeiro é ocupado, vão se aterrando e desaparecendo rios e lagos. Um exemplo é o morro do Castelo, que foi destruído e cuja terra foi para o Aterro do Flamengo. Aos olhos de hoje, entendemos que não se respeitou a geografia local, bem como o meio ambiente.

O desenvolvimento realmente assume suas características com a contribuição do capital estrangeiro que veio, junto com o capital nacional e estatal, contribuir para um novo processo de expansão e este devido ao desenvolvimento dos transportes públicos mais modernos como o bonde e o trem. O desenvolvimento do Rio, na questão urbanística, teve como marco fundamental o ano de 1870, com o inicio das construções de linhas férreas de bondes que demarcaram o território do Rio de Janeiro.

Para Weid (2000), os bondes e os trens urbanos foram essenciais para a expansão e organização do espaço urbano no Rio de Janeiro. Sem dúvida nenhuma, as ferrovias por extensas áreas das diversas freguesias da cidade para além do centro comercial do Rio promoveram a expansão da população, face ao advento do bonde. Os que podiam pagar logo se retiraram para as novas terras, seguindo o modelo da família Imperial, e assim as extensas fazendas foram fragmentadas em chácaras e depois em loteamentos. 
A necessidade de mudar o centro do Rio desenvolveu um fenômeno ainda maior que o esperado, pois com o advento do transporte publico áreas que antes estavam inacessíveis se tornaram alcançáveis. O texto informa que por volta de 1850 , o Rio de Janeiro fica contraditório, modernidades urbanistas ao lado de locais onde residem populações miseráveis. Voltando aos bondes, temos que considerar as colocações de Ferreira dos Santos sobre os bondes seguirem um caminho préexistente: "o bonde foi para zona sul, porque as razões de ocupação seletiva da área já eram uma realidade...".

Segundo Weid (2000), em 1892 o bonde chega a Copacabana, consolidando a Zona Sul da cidade. A construção desse ramal foi feita de acordo com os interesses do capital imobiliário, que desejava expandir naquela área.

O setor imobiliário tomou parte nessa campanha juntamente com as companhias de transporte. Até mesmo a situação do transporte fluvial foi, de certo modo, beneficiada, o que desenvolveu, por sua vez, as relações comerciais entre Niterói e o Centro. As freguesias rurais permaneceram por algum tempo como antes.

Falávamos da estrutura caótica do centro antes da chegada da família imperial e do desenvolvimento do comércio capitalista no Rio. Torna-se novamente necessário revermos as circunstancias. As reformas realizadas para dar um aspecto mais moderno e desenvolvido ao Rio foi na verdade, como bem entendido, um maqueamento da cidade, pois visava, na verdade, a retirada da parcela pobre do centro que habitava em imóveis insalubres e desgastados (cortiços). Essa atitude acabou por agravar a situação de moradia na cidade, uma vez que os deslocados, quase que na totalidade, não tinham condições de se recolocarem em áreas mais bem definidas e urbanizadas, o que veio favorecer a favelização da cidade. Essas pessoas logo tomaram para si os espaços não quistos pelos favorecidos socialmente; e acabou por ocupar as encostas dos morros da cidade, problema que ainda persiste.

Na realidade a situação do Rio de Janeiro é totalmente diferente dos demais Estados do país. Por ter convivido com um colonialismo tradicional não pôde se livrar prontamente dessa influência e, por sua vez, o capitalismo na se interessa por questões de planejamento urbano a não ser quando esse pode viabilizar altos lucros. 
A constituição do Rio de Janeiro na atualidade é devida a esses fenômenos do desenvolvimento do Centro e das áreas adjacentes. Seria caso de um intenso desarranjo político social. As reformas realizadas para adequar as áreas do Centro não obtiveram sucesso real, pois foram reformas feitas com o intuito de mascarar a imensa contradição social existente no Rio colonial e capitalista. E as áreas próximas ao centro comercial do Rio não tiveram um cuidado especial com o desenvolvimento de seu potencial; ficaram restritas à manutenção e sustentação de um centro problemático. Isso ainda se reflete nos dias atuais, uma situação desastrosa no mínimo.

\section{3}

\section{A Ocupação urbana na bacia do Canal do Mangue}

Na cidade do Rio de Janeiro, uma das suas características era a presença de pântanos, e um deles, acabou denominado de 'mangue', o qual tem origem no nome de uma planta da família das mirtáceas.

O imenso pântano que se estendia do Rossio Pequeno, atual Praça Onze de Junho, até sua embocadura estimada em cerca de 500 metros e largura variando de 70 a 100 metros, era um verdadeiro braço de mar. Desaguavam nessa enseada os rios que faziam parte do Sistema Iububuracica constituídos pelos rios Maracanã, Trapicheiros, Joana, esses dois últimos tributários do primeiro.

O Manguezal era navegável por embarcações de pequeno calado e interligava a Baía de Guanabara aos bairros da Tijuca e Andaraí, além do Rossio Pequeno. Os níveis das marés adicionados à forte pluviosidade, além do transbordamento d'água das lagoas existentes na cidade, acrescidas das enxurradas que desciam dos morros, assolavam essa área. As águas do Manguezal extravasavam entrando nos alagadiços e lagoas próximas, gerando dificuldades para o transito e doenças das mais variadas.

Existiam ilhas dentro do Manguezal, inclusive uma bem extensa, em frente ao Morro de São Diogo, a ilha dos Marinheiros.

$\mathrm{Na}$ época de D. João na região do 'mangue', só se tinha construído um longo e estreito aterro que servia para a passagem das carruagens do monarca e dos fidalgos 
para a Quinta da Boa Vista. Como o local era foco de mosquitos e de exalações desagradáveis, surgiu a ideia de se abrir um canal no vasto brejal.

Em 1835, o Governo Imperial resolveu acabar com essa vasta área alagada, construindo um estreito canal que recebesse não só as águas pluviais, mas também a dos riachos das redondezas.

Em 1857, através de Irineu Evangelista de Souza, o Barão de Mauá, obteve-se a concessão para construir por administração esse canal. Sua inauguração se deu em 1860 e a obra se estendia de Rossio Pequeno à Aguada dos Marinheiros.

As novas concepções urbanísticas copiavam as práticas das cidades europeias, que condenavam as ruas estreitas e sinuosas, assim "um dos maiores defeitos que se notam na parte antiga da cidade é a estreiteza e a grande sinuosidade de suas ruas, do que resultam não só dificuldades à circulação dos veículos e das pessoas a pé, mas ainda impedindo a renovação do ar viciado por tantas causas no interior das habitações” (UFRJ, 2002, pág. 376). A construção do Canal do Mangue seguia esta 'nova' concepção urbana, constituindo-se no eixo em torno do qual se alinhavam as extensas e largas avenidas projetadas.

Os estudos e projetos desenvolvidos há mais de um século por técnicos de alta capacidade tinham como preocupação dominante à drenagem clássica e o dessecamento de solos. Cabe ressaltar que o estado da ciência hidrológica e da tecnologia era ainda incipiente nesta época.

Logo depois de sua inauguração, em 1860, o Canal do Mangue havia se transformado em um problema de saúde pública. Esse canal, 15 anos após a sua inauguração, teria que ser totalmente recuperado e desobstruído. Em 1874 foi nomeada a Comissão de Melhoramentos da Cidade do Rio de Janeiro pelo Imperador e a Comissão das Águas, onde o Canal do Mangue era o eixo dos melhoramentos projetados.

A proposta era desobstruir o trecho já existente e o prolongamento do canal. Próximo a serra recolheria a grande quantidade de água proveniente das montanhas circunvizinhas, formando rios pouco caudais e enormes charcos. Os dois braços do canal se juntariam num tronco comum, nas imediações do largo do Matadouro, atual 
Praça da Bandeira e seria prolongado na direção das ilhas dos Melões e das Moças, com uma bacia de acumulação d'água (essa bacia de recepção ficava entre a Rua do Andaraí Grande, atual Rua Barão de Mesquita, e o Boulevard 28 de Setembro, já inaugurado pela Companhia Vila Isabel, e também já se pensava em construir ali a Universidade do Rio de Janeiro, um horto botânico e um zoológico). Daí até sua foz um único canal percorreria a superfície do terreno a ser aterrado até o saco de São Diogo, transformando os alagadiços em terrenos úteis.

Em 1876 foi completado o seu acabamento com a colocação de comporta junto à ponte, o assentamento do gradil de ferro e a arborização das alamedas marginais, onde foram plantadas mais de 700 palmeiras. Previa-se também a instalação de comportas dividindo o leito em tabuleiros de níveis diferentes para permitir sua utilização como navegação barata e até mesmo a recreação em grande parte de sua extensão. A Comissão, ao propor a utilização como meio de transporte, visava também à condução de passageiros e cargas, particularmente no transporte de material de construção.

No Governo do Presidente Rodrigues Alves, de 1902 a 1906, as obras do Cais do Porto exigiu o prolongamento do Canal do Mangue até o mar, tornando-se uma das maiores realizações do ministro da Viação, Dr. Lauro Muller, acabando com os alagadiços das antigas praias Formosas e dos Lázaros, tornando utilizável a enorme extensão de terra e procurando o controle das enchentes provocadas pelos rios, Comprido, Trapicheiro, Maracanã e Joana.

Em 1907 foram inauguradas importantes obras na região do Canal do Mangue, a construção dos viadutos na Estrada de Ferro Central do Brasil, entre as estações de São Diogo e São Cristóvão, sobre a atual Avenida Francisco Bicalho e outro nas ruas Figueira de Melo e São Cristóvão.

\section{4}

\section{A ocupação urbana na bacia do Rio Joana}


A expansão da cultura de açúcar, na região da Bacia do Rio Carioca e as áreas contribuintes à Bacia do Saco de São Diogo, os Rios Maracanã, Joana, Trapicheiros e Comprido foram grandes responsáveis pelo desmatamento das encostas e vales.

No século XIX, o plantio da cana-de-açúcar foi paulatinamente sendo substituído pelo do café, no Vale de Laranjeiras e nas encostas da Tijuca, até o Alto da Boa Vista, onde viviam, principalmente, os ingleses e franceses de alguma nobreza, no Rio de Janeiro.

O início do ciclo do café ampliou o desmatamento das encostas dos morros da Cidade. Com o tempo, ao serem transferidos para o interior do Estado, até as fronteiras de São Paulo e Minas, as plantações de café foram as grandes responsáveis pela expansão da ocupação do solo fluminense e os reativadores de sua economia.

Quanto às intervenções urbanas nesta região, a construção do porto e sua operação implicaram em grandes aterros na Baía de Guanabara com o desaparecimento de ilhas e estreitamento da foz dos rios Maracanã, Comprido, Joana e Trapicheiros, fazendo surgir o Canal do Mangue.

O primeiro porto da cidade na atual rua D. Manuel, próxima ao Fórum no Centro da Cidade, ainda no período do Brasil Colonial, o aterro da Lagoa do Boqueirão da Ajuda, hoje Passeio Público, o da Lagoa Sentinela e outras menores, foram as primeiras atuações bastante impactantes na cidade e na bacia do atual Canal do Mangue.

Outras intervenções sofridas nesta bacia, em meados do século passado, foram os dois terminais da Estrada Ferroviária da antiga Central do Brasil, próxima ao Campo de Santana e o da Estrada de Ferro Leopoldina, à margem esquerda do Canal do Mangue em seu último estirão.

Essas obras fracionaram a bacia original do Rio Joana transformando-a na bacia atual do Rio Joana, que juntamente com o Rio Maracanã formam o Canal do Maracanã, e na bacia do Rio Joana Inferior, com desembocamentos distintos nos Canais do Maracanã e do Mangue. 
A Bacia do Rio Joana faz parte da Bacia Hidrográfica do Canal do Mangue, ou seja, é uma sub-bacia, nas suas várzeas mais baixas, e resultou de várias obras que datam de mais de cem anos, através da modificação de manguezais, brejos, lagoas temporárias e alagadiços no litoral da Baía de Guanabara. Essa atuação antrópica levou 'a profundas modificações nos sistemas de escoamentos atuais, tanto superficiais como subterrâneos, notadamente nas áreas dos estirões finais das calhas fluviais urbanas. Fato esse que veio interferir em toda a macro-bacia do Canal do Mangue.

No sistema fluvial reunido nos rios Catumbi, Papa-Couve, Comprido, Trapicheiros, Maracanã e Joana, com as desembocaduras finais no Canal do Mangue, grandes enchentes passaram a ocorrer com maior regularidade e intensidade, mais pesadas e impactantes quanto maiores os índices pluviométricos e o nível de antropização das bacias contribuintes, agora centralizadas num único exutório na Baía de Guanabara. A reunião de bacias hidrográficas dispersas de pequeno e médio porte num único exutório era muita usada, pois além de permitir a recuperação de terrenos eram mais econômica e mais rápida as implantações hidráulicas, e se tornou uma prática rotineira.

A ocorrência de pesadas precipitações e a ocupação das áreas no início do século passaram a constituir um grave problema ambiental e foi se agravando com o desenvolvimento urbano e ocupacional das áreas de contribuição hídrica da bacia.

Nas áreas mais elevadas das bacias começou a ocorrer o processo de 'favelização', constituindo um cinturão periférico promotor de problemas mais complexos: aumento das erosões e disposições na planície, presença de grandes massas de lixo disperso, enxurradas tornaram-se mais volumosas e enérgicas, gerando poluição hídrica concentrada nas calhas fluviais.

O excessivo grau de artificialização da urbanização do solo da bacia, tais como: impermeabilizações, capeamentos, traçado e demais características hidráulicas impostas aos Canais do Mangue, do Maracanã e aos demais subafluentes à jusante, com regiões densamente ocupadas, incluindo terminais rodoferroviários, nós rodoviários da Estrada de Ferro Leopoldina e a Praça da Bandeira, tornou inevitável a 
forte concentração de vazões de enchentes nos principais canais referidos anteriormente.

\section{5}

\section{As enchentes nas bacias hidrográficas urbanas}

A história é repleta de simbologias relacionadas à água. O mito do Dilúvio pode ter se originado na Suméria, no Oriente Médio, com a inundação na confluência de dois grandes rios, aproximadamente no ano 2900 "A.C.”. O episódio teve tal impacto que a lista Suméria de reis divide a história em antes e depois da inundação; os oitos reis anteriores são conhecidos como 'antedilúvios'. Um dos posteriores ao dilúvio é Gilgamesh, que viveu aproximadamente em 2600 "A.C” e com o tempo ganhou estatura de lenda. (COVARRUBIAS, 2001).

A enchente que provoca o extravasamento do leito maior de um corpo hídrico, devido a uma chuva determinada, acarreta prejuízos econômicos e o faz de modo catastrófico e, assim, ela é considerada 'enchente histórica'. Contudo, se ela inunda uma área desabitada, sem importância econômica, ela é denominada de 'enchente notável'.

As impermeabilizações do solo nos trechos inferiores dos rios, no passado, impuseram que as águas das chuvas se juntassem em pequenos braços e se espraiassem por extensas áreas marginais antes de atingirem o mar propriamente dito (COVARRUBIAS, 2001).

Registros pluviométricos que se dispõe para a Cidade do Rio de Janeiro datam do ano de 1851. Antes disso só se dispõe de notícias de enchentes históricas, através da narrativa de cronistas da época ou viajantes estrangeiros que as registravam em seus diários de viagem.

A primeira inundação que se tem notícia, gerada por uma enchente, ocorreu no século XVI e não se tem registro escrito. Ela foi mencionada por cronistas posteriores no Século XVII.

Contam sobre uma ressaca, em período de maré alta e chuva muito intensa, não se precisando a data, quando a Rua Direita, atual Rua Primeiro de Março, foi 
alagada, assim como os charcos da cidade transbordando as Lagoas de Santo Antônio, atual Largo da Carioca, do Boqueirão, atual Passeio Público e do Outeiro, atual Rua do Lavradio, interligando-as e formando um lago-mar.

Este lago-mar estendeu-se da Prainha, atual Praça Mauá, à Lagoa da Sentinela, atual Rua Frei Caneca, de tal forma que os morros então habitados do Castelo, atual Rua Graça Aranha e México, de São Bento, atual Rua do Senado, se transformaram em ilhas.

As inundações por águas de chuva vêm aumentando continuamente em centros urbanos. A cada ano elas surgem com ímpeto redobrado, acarretando a destruição de cidades e vilas, doenças e mortes. O crescimento populacional desordenado em áreas urbanas de forma acelerada e somente em algumas a drenagem urbana foi considerada fator preponderante no planejamento da sua expansão. Nas cidades o aumento das áreas impermeabilizadas ocorre, em geral, a partir das zonas mais baixas, próximas às várzeas dos rios ou a beira mar, em direção às colinas e morros, em face da necessária interação da população com os corpos hídricos.

Desde o século XVIII, já há informações a respeito de grandes temporais na cidade do Rio de Janeiro com inúmeros casos de enchentes com vítimas.

10/02/1811 - Inundações, a catástrofe que castigou o Rio de Janeiro, entre os dias 10 e 17 de fevereiro de 1811, ficaram conhecidas como "águas do monte”, em virtude da grande violência com que a enxurrada descia dos morros que cercavam a cidade. Grande parte do Morro do Castelo desmoronou, provocando o desabamento de muitas casas. Fala-se em muitas vítimas e enormes prejuízos materiais, mas os verdadeiros números são desconhecidos, pois o jornal da época a Gazeta de Notícias não dava importância a estes acontecimentos, segundo Vieira Fazenda. Tal foi a magnitude deste temporal que o príncipe regente ordenou que as igrejas ficassem abertas para acolher os desabrigados e encomendou estudos sobre as causas da catástrofe. A construção da muralha do Castelo-Fortaleza de São Sebastião foi a solução encontrada para evitar novos desabamentos de casas e mais mortes. 
17/03/1906 - Inundações, conhecido como uma das maiores que castigou a cidade. Naquele dia, $165 \mathrm{~mm}$ precipitaram em 24 horas. O transbordamento do Canal do Mangue provocou alagamento em quase toda a cidade e houve desmoronamentos com mortes nos morros de Santa Tereza, Santo Antônio e Gamboa.

03/04/1924 - Inundações, fortes chuvas provocaram o transbordamento do Canal do Mangue, inundação em vários bairros, além da Praça da Bandeira, e desabamentos de barracos, com vítimas, no Morro de São Carlos.

29/01/1940 - $112 \mathrm{~mm}$ causaram alagamentos em quase toda a cidade, inundação da Praça da Bandeira e mortes por desabamentos no bairro de Santo Cristo.

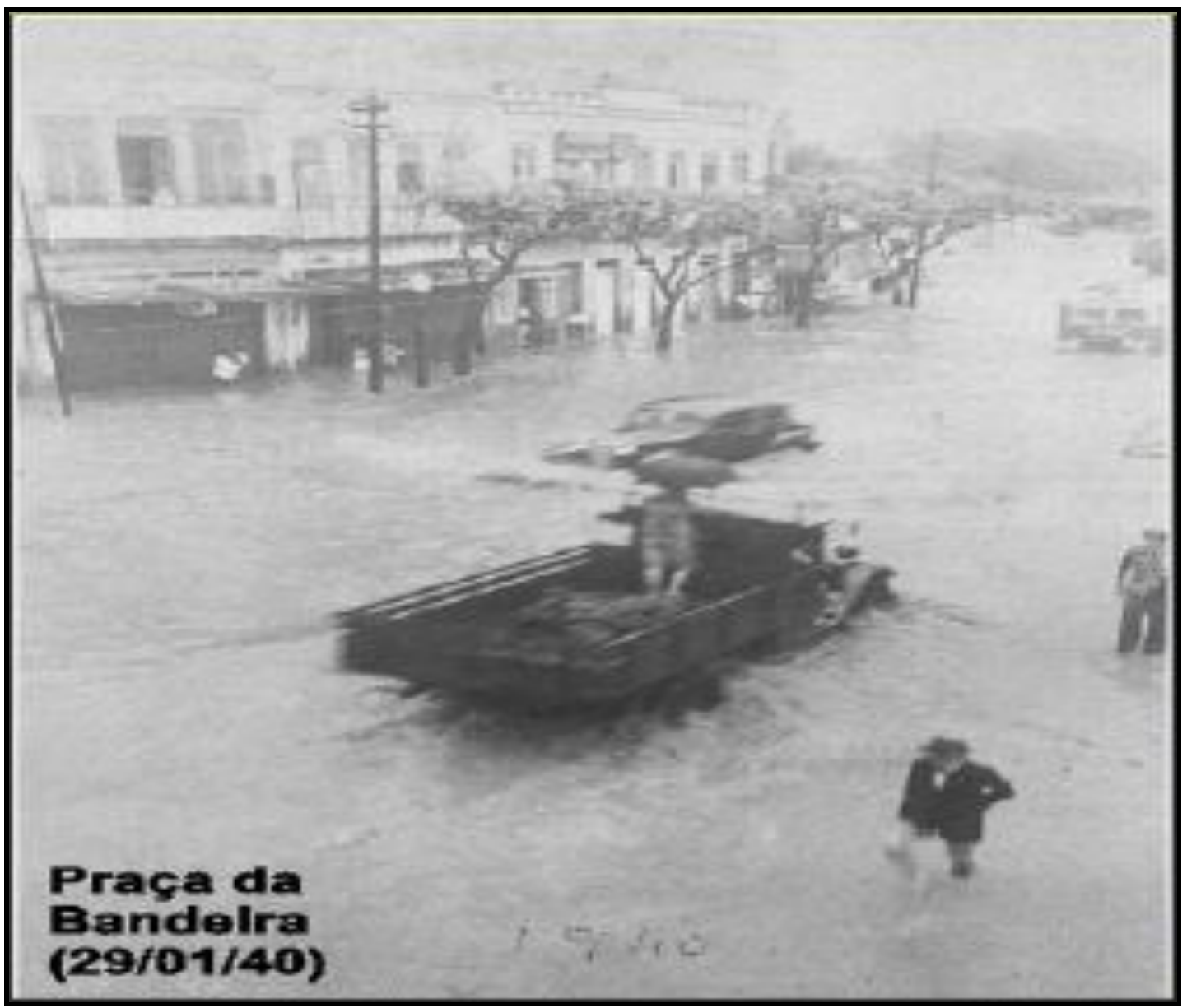

Figura 1 - Enchente da Praça da Bandeira Fonte: PLANÁGUA/SEMADS/GTZ, 2001. 
06/01/1942 - Inundação na bacia do Canal do Mangue foi $132 \mathrm{~mm}$ de chuva, com desabamento que soterrou, com morte, cinco pessoas no Morro do Salgueiro.

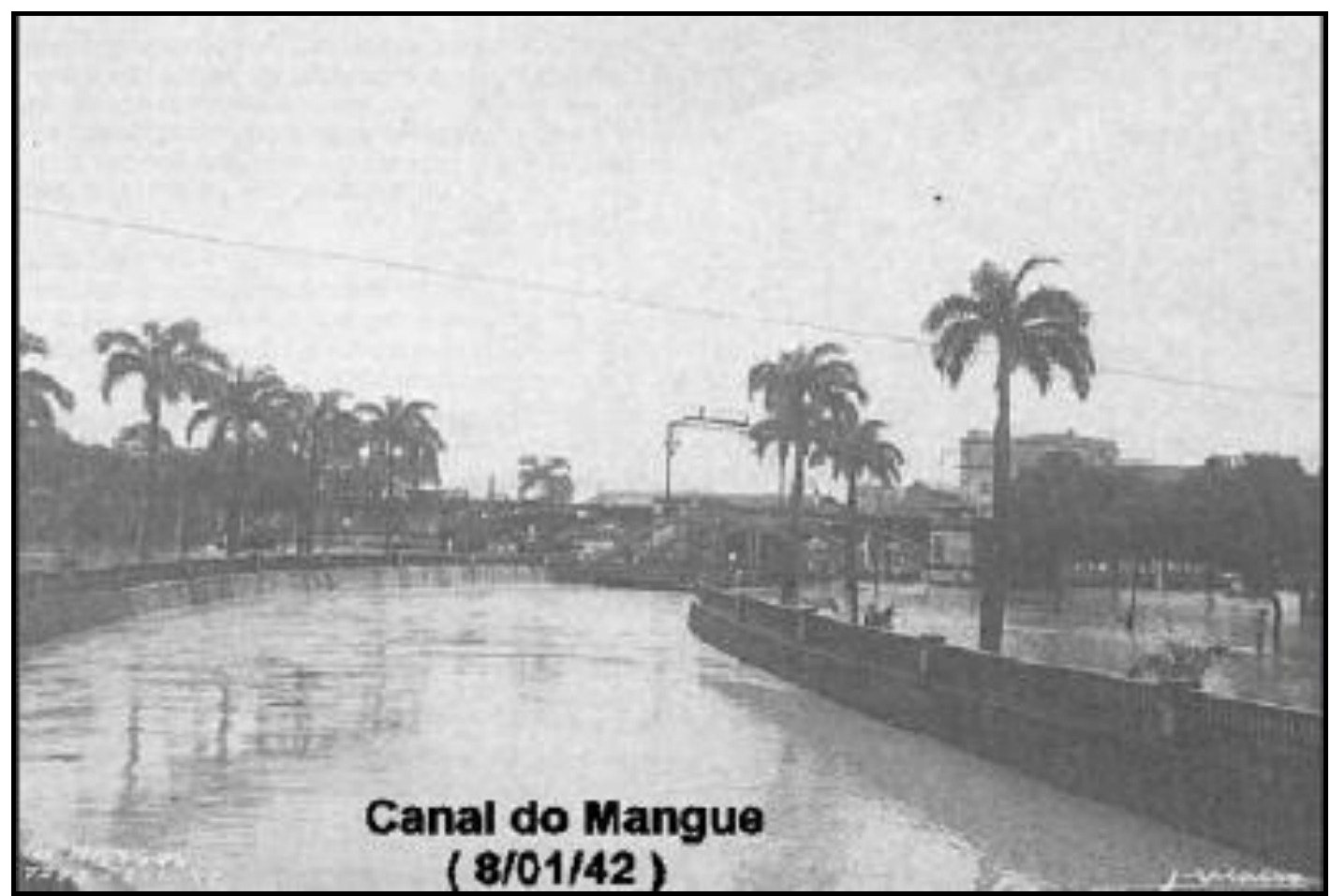

Figura 2 - Enchente no Canal do Mangue em 1942

Fonte: PLANÁGUA/SEMADS/GTZ, 2001.

15/01/1962 - Inundação, vinte e cinco mortos, centenas de desabrigados, temporal que totalizou $242 \mathrm{~mm}$ e provocou o transbordamento do Canal do Mangue e do Rio Maracanã e deslizamentos em vários pontos.

02/01/1966 - Enchentes e deslizamentos nos Estados da Guanabara e Rio de Janeiro, duzentos e cinquenta mortos, cinquenta mil desabrigados.

20/01/1967 - Deslizamento, Rua General Glicério, Laranjeiras, duzentos mortos, trezentos feridos, devido às fortes chuvas, uma casa e dois edifícios foram soterrados entre as ruas Belizário Távora e General Glicério. Enchentes e deslizamentos, nos Estados da Guanabara e Rio de Janeiro, trezentos mortos e vinte e cinco mil feridos. 
03/12/1982 - Inundação, seis mortos, causou deslizamentos no Morro Pau da Bandeira, inundando várias ruas com o transbordamento do Rio Faria-Timbó.

20/03/1983 - Um grande temporal caiu na madrugada de 20 de março de 1983, provocando a desabamento de casas e a morte de cinco pessoas em Santa Teresa, onde a chuva atingiu $189 \mathrm{~mm}$. O transbordamento de rios e canais em Jacarepaguá deixou mais de cento e cinquenta desabrigados.

24/10/1983 - Inundação, Rio de Janeiro, treze mortos, forte temporal, com deslizamento de terra no Morro do Pavãozinho.

26/02/1987 - Enchente, Petrópolis, Teresópolis e Rio de Janeiro, duzentos e noventa e dois mortos, vinte mil desabrigados. Em razão destas chuvas que registravam cento e setenta e uma vítimas fatais em Petrópolis e noventa e quatro no município do Rio de Janeiro foi decretado nesta o Estado de Emergência e com o agravamento da situação no dia 22 Estado de Calamidade Pública.

01/02/1988 - Enchente em Petrópolis e na Baixada Fluminense, duzentos e setenta e sete mortos e dois mil desabrigados.

12/02/1988 - Deslizamento, Morro Dona Marta, Rio de Janeiro, seis mortos, quarenta feridos e trezentos desabrigados, uma tela usada em uma obra de contenção de encosta rompeu-se sob o peso do lixo e da lama, acumulados durante uma semana de fortes chuvas. A enxurrada destruiu vários barracos.

19/02/1988 - Enchente e deslizamento, Rio de Janeiro, duzentos e oitenta e nove mortos, cerca de setecentos feridos, dezenove mil desabrigados, prejuízos US\$ 935 milhões.

17/01/1991 - Enchente, Rio de Janeiro, vinte e cinco mortos e oito feridos.

Jan/1999 - Enchente, Rio de Janeiro e municípios do Vale do Paraíba e região Serrana, quarenta e um mortos, setenta e dois feridos e cento e oitenta famílias desabrigadas. 
Jan/2000 - Enchente, municípios do Petrópolis, Teresópolis, Casimiro de Abreu e Barra Mansa. Vinte e dois mortos, sessenta feridos e mais de cem famílias desabrigadas.

Fev/2003 - Enchente, municípios da Região Serrana, Sul e Norte Fluminense. Trinta e seis mortos, noventa e cinco feridos e oitocentos desalojados e desabrigados.

Abril/2010 - Enchentes na cidade do Rio de Janeiro (Figuras 3 e 4).

Janeiro/2011 - Grande catástrofe nas Cidades Serranas, como Nova Friburgo, Teresópolis, Itaipava.

Abril/2011 - Enchentes na cidade do Rio de Janeiro (Figuras 5, 6 e 7).

Observa-se que mesmo com o passar dos anos os mesmos fatos se repetem e não têm sido aplicadas medidas cabíveis, pra melhoria desta situação.

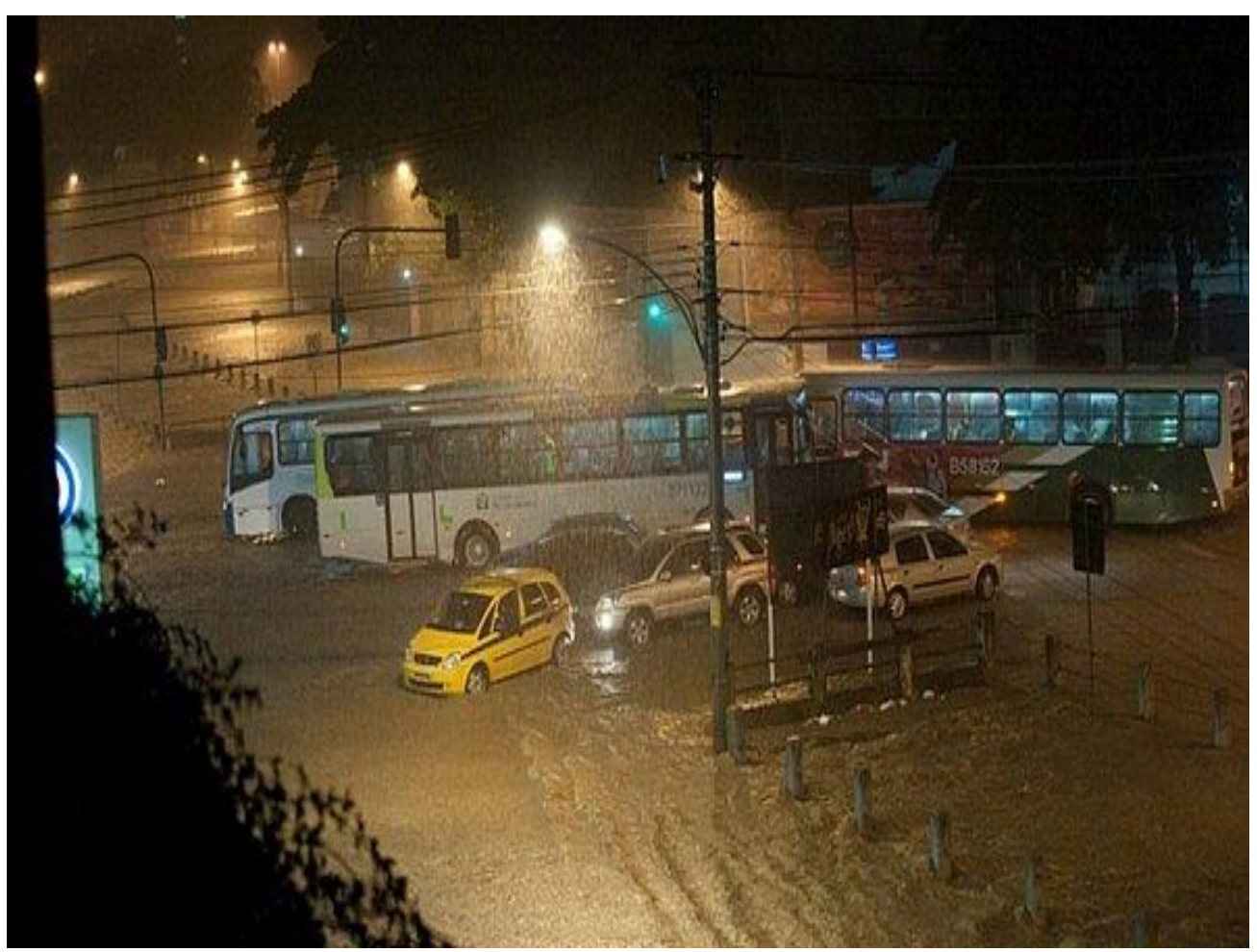

Figura 3 - Rio Joana - Abril de 2010

Fonte: RIO AGUAS, 2011. 


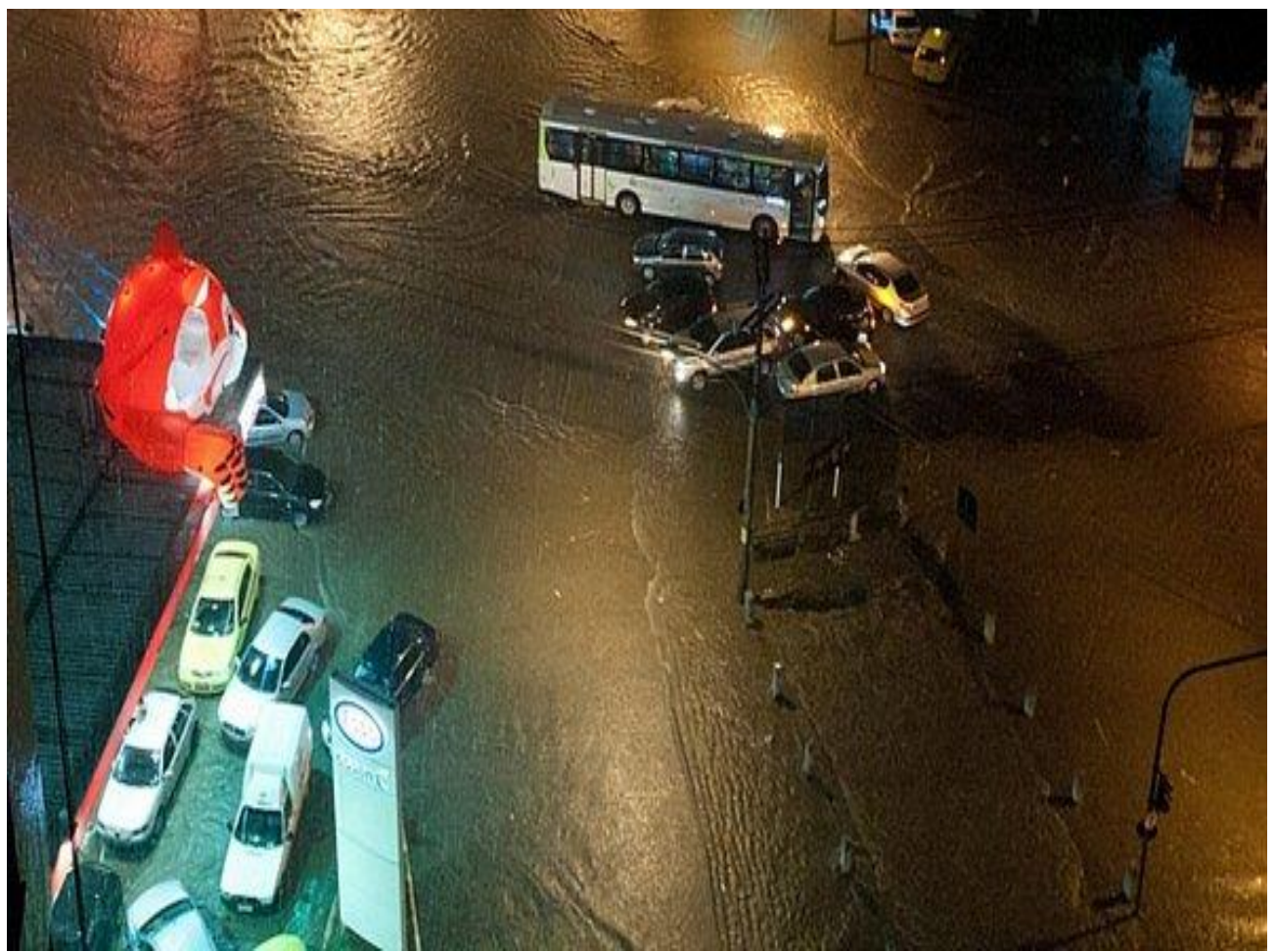

Figura 4 - Rio Joana - Abril de 2010

Fonte: RIO AGUAS, 2011.

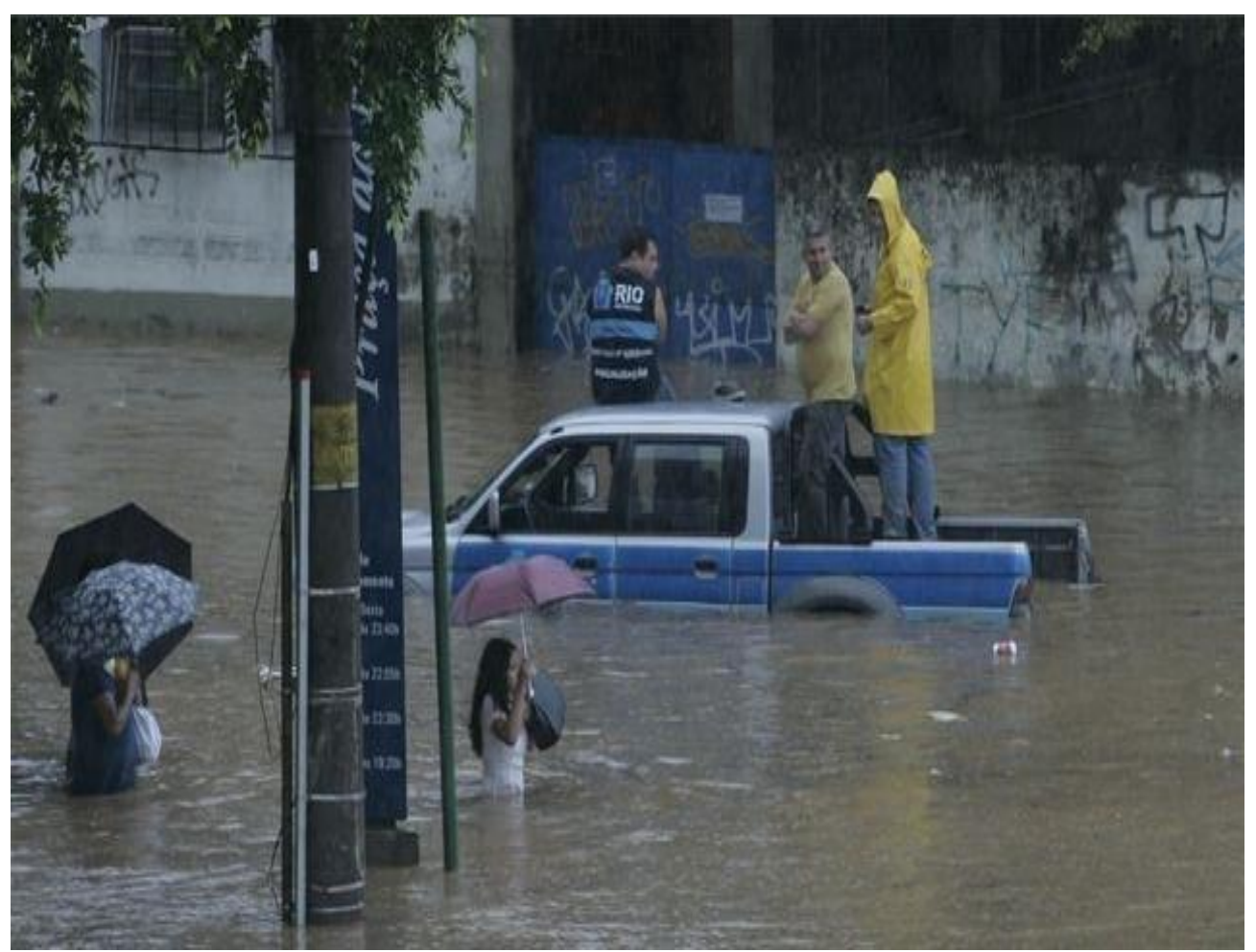

Figura 5 - Enchente da Praça da Bandeira em Abril de 2011 Fonte: RIO AGUAS, 2011. 


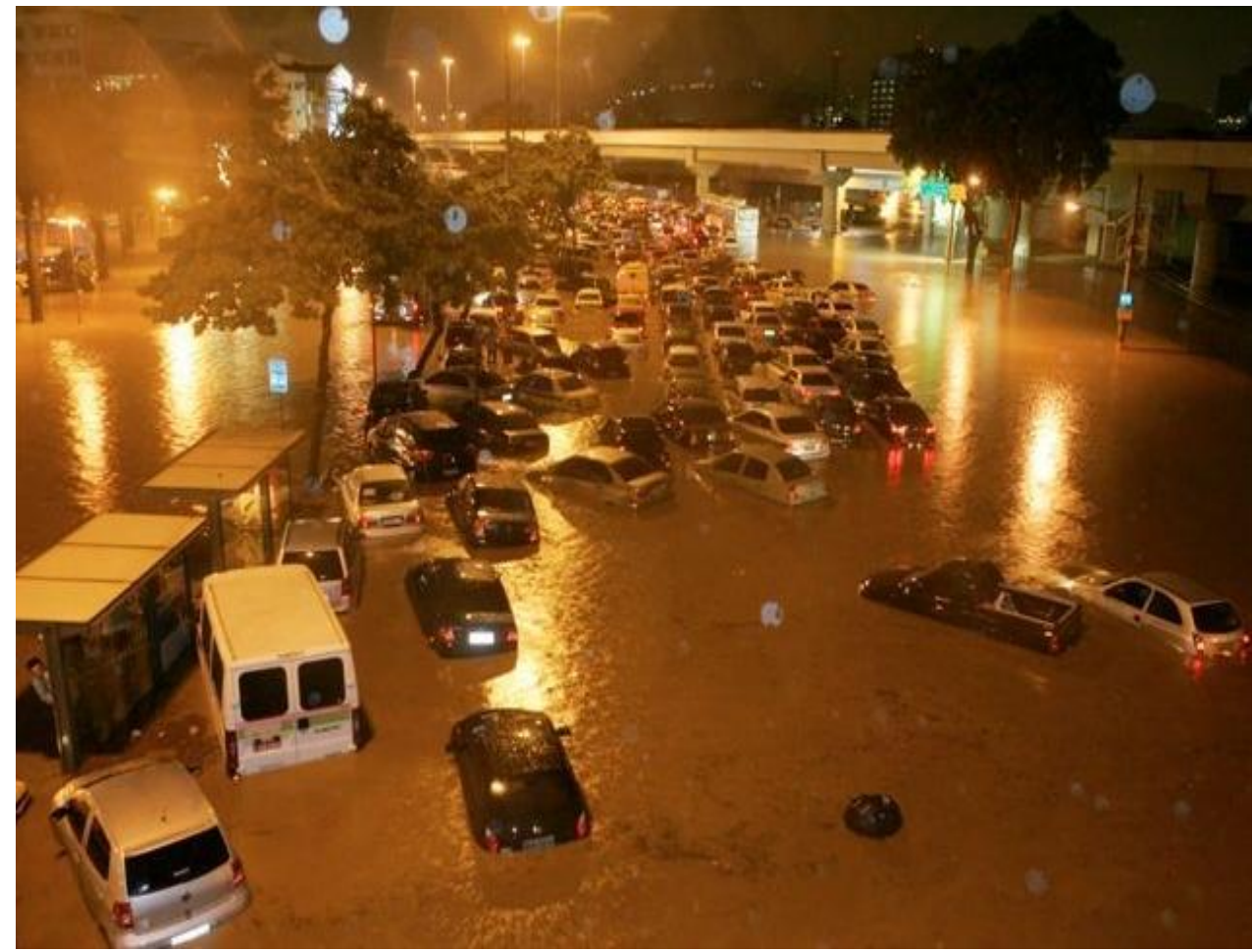

Figura 6 - Enchente da Praça da Bandeira em Abril de 2011

Fonte: RIO AGUAS, 2011.

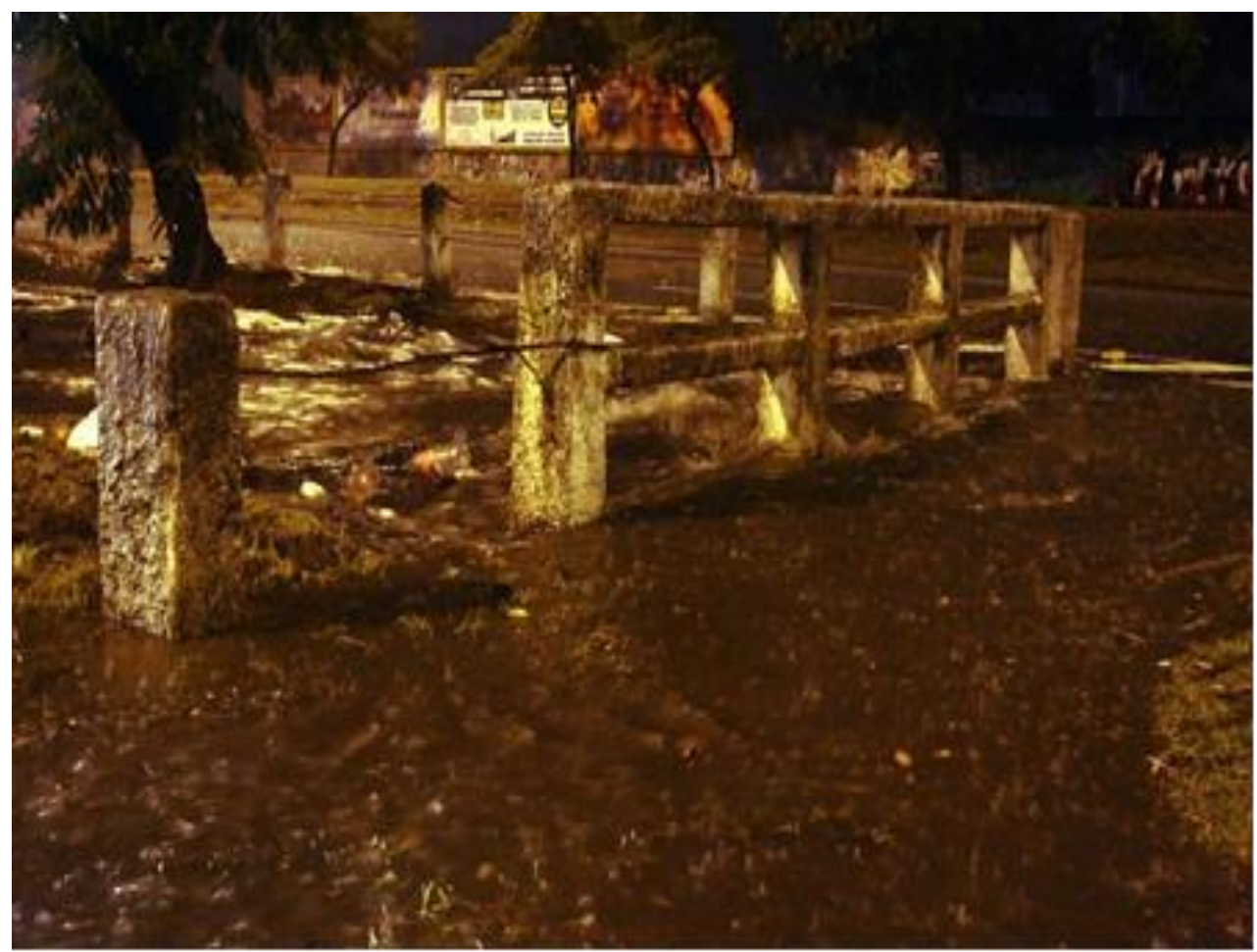

Figura 7 - Rio Joana - Abril de 2011

Fonte: RIO-ÁGUAS, 2011. 


\section{3}

\section{LOCALIZAÇÃO DA ÁREA DE ESTUDO}

\section{1}

\section{Caracterização Física da Bacia}

O Rio Joana nasce junto ao Pico do Andaraí Maior, na Reserva Florestal do Grajaú, com aproximadamente 600 metros de altitude, a oeste da Bacia do Canal do Mangue. Seu estirão inicial denomina-se Rio Perdido, na vertente vizinha ao sul recebe o Rio Jacó e passa a chamar-se Joana. Acima da confluência com o Rio Jacó, a bacia é quase toda ocupada por mata nativa densa e vegetação arbustiva com gramíneas.

Ao descer o bairro do Grajaú o curso d'água torna-se uma galeria urbana percorrendo área muito antropizada, reaparecendo como canal aberto na confluência das ruas Barão de Mesquita e Maxwell, quando recebe o Rio Andaraí, no bairro do Andaraí, vindo do morro e favela do mesmo nome. Desse ponto em diante recebe as águas de drenagem dos bairros do Andaraí, Vila Isabel e parte da Tijuca, assim como da Serra do Engenho Novo, até um pouco antes do cruzamento com a linha ferroviária da Supervia, junto ao Campus da Universidade Estadual do Rio de Janeiro, onde volta a ser capeado. Sua foz situa-se na confluência com o Rio Maracanã, em frente à Estação de São Cristóvão, na cota 1,63 m, após fluir por 7.900 m (UFRJ, 2002, pág. 58).

A bacia do Rio Joana com uma área de 1.190 ha $\left(11,9 \mathrm{~km}^{2}\right)$ é uma sub-bacia da bacia do Canal do Mangue com área total de 4.200 ha (42 km), assim como as outras sub-bacias dos Rios Maracanã, Trapicheiro e Comprido. Ela é ocupada parcialmente por floresta de Mata Atlântica e por vegetação arbustiva de pequeno porte e gramíneas, geralmente no trecho inferior das encostas. As áreas de cotas mais altas dos morros foram ocupadas de forma desordenada por comunidades de baixa renda, ocasionando a degradação no recobrimento florístico original, agravada pelo carreamento de grande quantidade de lixo gerado por essas comunidades e lançados nas encostas. 


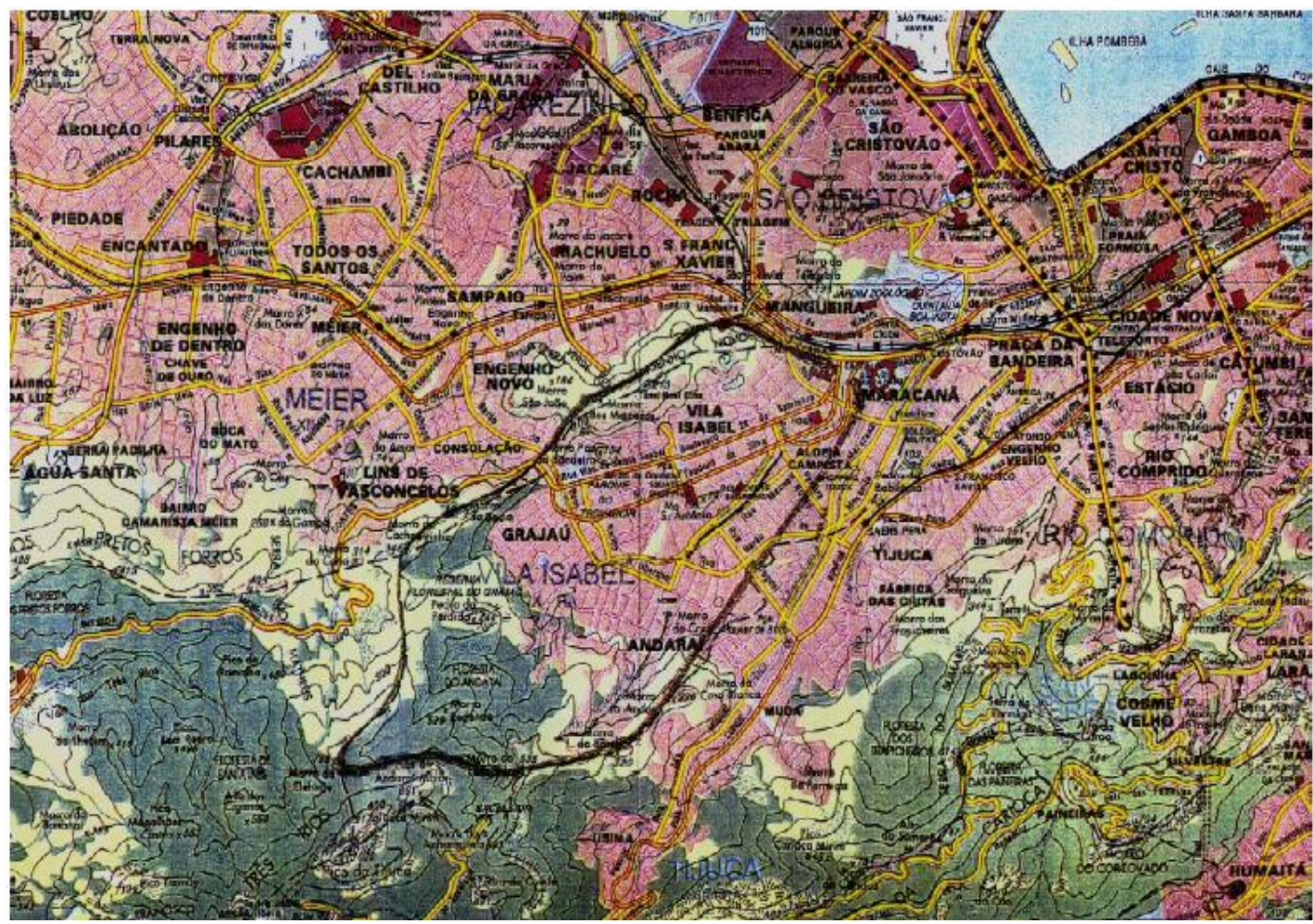

Figura 8 - Planta de situação da Bacia do Rio Joana

Fonte: UERJ, 2002 


\section{4}

\section{Ações para mitigação do efeito das enchentes}

As enchentes são 'eventos naturais' condicionadas ao clima, às chuvas intensas de verão e às características do relevo. No regime natural do rio, faz parte a variação de vazão e de cotas, da estiagem à enchente. As enchentes se formam quando chuvas intensas caem no solo já saturado por chuvas anteriores, sem capacidade de absorção natural. Os efeitos das enchentes são atribuídos em grande parte as intervenções humanas, desta forma ações necessárias para minimizá-los dependem, principalmente, medidas não convencionais em drenagem urbana.

Nas áreas urbanizadas, os rios são tratados como se fossem compartimentos isolados, às vezes canalizados ou retificados, comprometendo seus leitos e margens naturais, bem como afetando as interações biológicas com as áreas marginais.

A reversão deste processo é difícil. A recuperação de rios e córregos nas áreas urbanas só é possível onde há espaço para ampliação dos seus leitos, melhorando assim o problema do escoamento das enchentes. Quando há limitação de áreas disponíveis, devem-se buscar outras soluções possíveis adaptadas às necessidades de evolução natural, como por exemplo, a ampliação do leito em somente uma das margens.

O custo-benefício deve ser levado em conta e ser bem estudado, considerando-se os custos para manter a evolução natural de longo prazo, avaliando se são maiores do que aqueles relativos à construção e manutenção de obras hidráulicas convencionais. Quando se decide qual tipo de recuperação num rio urbano ou rural, pode-se com o auxílio de uma equipe multidisciplinar, agregar ideias e planejar soluções integradas onde o controle de enchentes e a valorização ecológica estejam presentes. Ainda não existe um termo técnico na engenharia de recursos hídricos para esse tipo de intervenção. Revitalização de rios é, por enquanto, o termo mais empregado.

Na Europa, atualmente em muitos países, as áreas marginais de inundação têm uso restrito e às vezes são transformados em áreas de lazer, com quadras de esportes, 
jardins, sendo permitida, inclusive, a balneabilidade fluvial, à medida que a questão da poluição hídrica vai sendo resolvida.

O processo de recuperação natural exige conhecimentos da dinâmica morfológica, do ecossistema aquático e, principalmente, a compreensão e a aceitação da população ribeirinha. A recuperação do curso de água deve ter um planejamento vinculado aos seguintes objetivos: revitalização do curso d'água; ampliação do leito do rio e melhores condições para o escoamento das enchentes; reconstituição da continuidade de ecossistema do curso d'água; restabelecimento de faixas marginais de proteção e da mata ciliar; criação de atrativos para o lazer - acesso à água e melhorias na paisagem.

As principais atividades para alcançar esses objetivos, quando e onde for possível aplicar as técnicas de engenharia ambiental, podem ser: quebra-correntes de gabiões, pedras e ou troncos de árvores, plantio em áreas sujeitas à erosão e outros, em substituição às obras hidráulicas convencionais de engenharia. Além disso, devese executar a remoção de obstáculos ao escoamento.

Apesar de esse conceito ser novo na engenharia já começa a despertar interesse em vários estados brasileiros. No entanto, certamente será absorvido a médio e longo prazo, a exemplo da experiência estrangeira.

Levando em consideração os prejuízos das inundações, que estão intimamente ligados a fatores e interferências atribuídos as ações do homem, se fazem necessárias reavaliar práticas e conceitos até então adotados, de maneira que novas medidas venham compor o elenco de ações para evitar ou amenizar as enchentes e seus prejuízos e conviver com elas.

A urbanização, concentração populacional e bens materiais nas áreas com risco de inundações, isto é, ao longo das margens dos rios e nas regiões de baixada, vão diferenciar o número e tipo de ações e práticas recomendáveis. Seja qual solução adotada, o fundamental é não se perder a visão global da bacia hidrográfica, elegendo-a como unidade de gestão participativa, envolvendo o poder público, a sociedade organizada e setores produtivos e acadêmicos especializados. 
As ações devem estar integradas ao planejamento municipal, estadual e nacional e devem levar em consideração os seguintes aspectos, que serão tratados $\mathrm{Na}$ tabela 1:

Tabela 1 - Ações para mitigação dos efeitos das enchentes em Bacias Hidrográficas

\begin{tabular}{|c|c|}
\hline ACCÕES & DESCRIĈ̃̃O \\
\hline $\begin{array}{l}\text { Ações } \\
\text { relativas à } \\
\text { Gestão dos } \\
\text { Recursos } \\
\text { Hídricos }\end{array}$ & $\begin{array}{l}\text { - Reduzir as vazões máximas de enchentes, através do aumento e } \\
\text { recuperação em áreas de retenção de forma natural, artificial ou } \\
\text { combinadas, permitindo aumentar a capacidade de infiltração das águas } \\
\text { de chuvas no solo; } \\
\text { - Manter a capacidade de escoamento dos cursos de água, com uma } \\
\text { conservação sistemática, política de fiscalização na ocupação das } \\
\text { margens e descarte de lixo, adotando critérios rigorosos, com relação } \\
\text { aos projetos do curso d'água. }\end{array}$ \\
\hline $\begin{array}{l}\text { Planejamento } \\
\text { do Uso } \\
\text { e Ocupação } \\
\text { Racional } \\
\text { do Solo }\end{array}$ & $\begin{array}{l}\text { - As áreas sujeitas à inundação, como um meio mais econômico de } \\
\text { assentamento, têm que ser evitadas para diminuir riscos e prejuízos } \\
\text { maiores das enchentes; } \\
\text { - Recuperar ou preservar as áreas de retenção e de infiltração de águas } \\
\text { das chuvas; } \\
\text { - Promover divulgação e informação dos riscos que as enchentes } \\
\text { envolvem, localizando e delimitando as áreas inundáveis; } \\
\text { - Os investimentos públicos nessas áreas e influência devem ser } \\
\text { limitados para reduzir o estímulo da iniciativa privada }\end{array}$ \\
\hline $\begin{array}{l}\text { Ações de } \\
\text { Manejo } \\
\text { adequado na } \\
\text { agricultura }\end{array}$ & $\begin{array}{l}\text { - Manter áreas inundáveis e desenvolver culturas adaptáveis; } \\
\text { - Plantar e cultivar espécimes em áreas suscetíveis, para contribuição } \\
\text { da diminuição das taxas de erosão; }\end{array}$ \\
\hline $\begin{array}{l}\text { Ações de } \\
\text { Prevenção } \\
\text { Ambiental }\end{array}$ & $\begin{array}{l}\text { - Ampliar as áreas verdes; } \\
\text { - Intensificar o controle da poluição hídrica; }\end{array}$ \\
\hline
\end{tabular}

Fonte: Adaptado de PLANÁGUA/SEMADS/GTZ (2001) 


\section{5}

\section{Análise da problemática das enchentes na bacia hidrográfica do Rio Joana e alternativas para minimizá-las}

O curso do rio Joana tem um longo trecho coberto desde a junção dos rios Perdido e Jacó, até a Rua Barão de Mesquita, no bairro da Tijuca. No trecho a jusante desta galeria, o Rio Joana segue em canal aberto até a travessia da Rua Pereira Nunes, a partir de onde possui um pequeno trecho coberto, na Av. Prof. Manoel de Abreu, seguindo novamente em canal aberto, ao longo desta avenida até a confluência com a Rua Maxwell, onde iniciam os problemas de inundação.

A área compreendida entre a confluência das Av. Prof. Manoel de Abreu e Rua Maxwell, até as proximidades do estádio Célio de Barros e Av. Presidente Castelo Branco constitui o trecho mais crítico de inundações frequentes na bacia do Rio Joana. A partir da travessia sob a Av. Presidente Castelo Branco e da linha férrea, o Rio Joana segue em galeria fechada até sua foz, no Rio Maracanã. Este trecho apresenta importantes restrições de escoamento, causando o represamento de montante. $\mathrm{O}$ estudo de remanso mostrou que ocorrem restrições devido ao efeito de remanso no desemboque do Rio Joana no Rio Maracanã, no qual durante eventos de cheia, ocorrem deságues em seção totalmente afogada.

O desvio do curso do Rio Joana com mudança do seu exutório do Rio Maracanã para a baía de Guanabara tem a função de aliviar a afluência de desconcentração de volume jusante das vazões ao trecho final do Rio Maracanã, possibilitando um melhor aproveitamento de sua calha à jusante da foz do Joana, melhorando o escoamento na parte de jusante do rio Maracanã.

O sistema de obras hidráulicas proposto para a redução do risco de inundações na bacia hidrográfica do canal do Mangue é composto por reservatórios de detenção, galerias de reforço, galerias de derivação, túnel e galeria de desvio. Este sistema prevê a reconfiguração da macro-drenagem da bacia hidrográfica do Canal do Mangue de modo a possibilitar a veiculação das vazões de projeto para o período de recorrência, (tempo de recorrência) $\mathrm{TR}=25$ anos. 
O sistema de derivação de vazões do Rio Maracanã para o Rio Joana será composto por uma galeria com origem no trecho do rio próximo à Praça Vanhargem, passando em seguida sob a Rua Felipe Camarão até atingir o Rio Joana, na Av. Prof. Manoel de Abreu. Esta galeria foi projetada com capacidade de vazão de $25,0 \mathrm{~m}^{3} / \mathrm{s}$. A construção da galeria de derivação do Rio Maracanã para o Rio Joana irá regularizar o escoamento que atualmente ocorre de maneira superficial na Rua Felipe Camarão.

As obras de reforço de galeria no Rio Joana, no trecho situado entre a Rua Felipe Camarão e a entrada do túnel de desvio, irão possibilitar a veiculação da vazão proveniente do Rio Joana, somada ao aporte decorrente da galeria de derivação da Rua Felipe Camarão, após os devidos amortecimentos dos picos dos hidrogramas devido aos reservatórios de detenção.

A galeria de reforço será paralela à galeria existente e terá seção 5,00 x 2,50, com declividade de fundo $\mathrm{i}=0,15 \%$, possibilitando à veiculação de uma vazão de $31,2 \mathrm{~m}^{3} / \mathrm{s}$. A vazão de projeto a ser obtida com o reforço proposto deverá ser de 100 $\mathrm{m}^{3} / \mathrm{s}$.

Complementando-se o desvio do Rio Joana através de um túnel com início na praça Pres. Emílio Garrastazu Médici e desemboque na Baía de Guanabara, próximo a foz do Canal do Mangue. Este túnel terá uma seção aproximada (equivalente) a 38 $\mathrm{m}^{2}$ e terá a capacidade de vazão aproximada de $100,0 \mathrm{~m}^{3} / \mathrm{s}$.

As obras como canalização, aterros, retificação, diques e muros, visando reduzir inundações locais, acabam acarretando aumento das enchentes à jusante. Contudo, mesmo conscientes dessas consequências, estas muitas vezes se fazem necessárias para o controle das enchentes e proteção da população já estabelecida nas áreas inundáveis. Assim, como forma de conter o agravamento contínuo das enchentes, é indispensável que se faça uma compensação das perdas de detenção natural ocasionadas pelas obras, complementando-as com outras medidas de retenção na própria bacia.

A drenagem urbana consta de dois sistemas principais: a micro-drenagem e a macro-drenagem. O sistema de micro-drenagem é realizado por meio de condutos, destinados a receber e conduzir as águas das chuvas que vêm diretamente das construções lote, ruas e praças. A macro-drenagem consiste na drenagem da rede 
natural, pré-existente à urbanização, constituída por rios e córregos que podem receber obras, as quais os modifiquem e complementem, tais como canalizações, barragens, soleiras, diques, alargamentos e outras.

Nos reservatórios de detenção, como medida de controle de escoamento na micro-drenagem tradicional, é comum drenar a área através de condutos pluviais até um coletor principal ou riacho urbano. Esse tipo de intervenção acaba transferindo a jusante, o aumento do escoamento superficial com maior velocidade.

A impermeabilização e a canalização produzem aumento na vazão máxima e no escoamento superficial. Para que esse acréscimo de vazão máxima não seja transferido para jusante, utilizamos o amortecimento do volume gerado através de dispositivos como: tanques, lagoas e pequenos reservatórios abertos ou enterrados, entre outros. Essas medidas são denominadas de controle a jusante.

O objetivo das bacias ou reservatórios de detenção é minimizar o impacto hidrológico da redução da capacidade de armazenamento natural da bacia hidrográfica. Dentre as vantagens e desvantagens desse tipo de intervenção tem-se: custo reduzido, se comparado a um grande número de controles distribuídos; custo menor de operação e manutenção; facilidade de administrar a construção; dificuldade de achar local adequado; custo de aquisição da área; reservatórios maiores têm oposição por parte da população.

Esse tipo de intervenção tem sido utilizado quando existem restrições por parte da administração municipal ao aumento da vazão máxima devido ao desenvolvimento urbano e foi implantado em muitas cidades de diferentes países. $\mathrm{O}$ critério normalmente utilizado é de que a vazão máxima da área, com o crescimento urbano, deva ser menor ou igual à vazão máxima das condições preexistentes para um tempo de retorno escolhido.

Reservatórios podem ser projetados com dimensões para manterem uma lâmina permanente de água (retenção), ou secarem após o seu uso, durante uma chuva intensa e podem ser utilizados também em outras finalidades (detenção). Quando a quantidade de sedimentos produzida é significativa, esse tipo de dispositivo pode reter parte dos sedimentos para que sejam retirados do sistema de drenagem. 
A vantagem da manutenção da lâmina d'água e do consequente volume morto é que não haverá crescimento de vegetação indesejável no fundo, sendo o reservatório mais eficiente para controle da qualidade da água. O seu uso integrado junto a parques pode permitir um bom ambiente recreacional. Esse dispositivo quando seco também pode ser utilizado para outras finalidades, contribuindo para melhorar o lazer da população, atuando como controle de desmatamento e das enchentes urbanas nos períodos chuvosos.

\section{1}

\section{Alternativas de intervenção na bacia do Rio Joana}

O curso do rio Joana tem um longo trecho tamponado desde a junção dos rios Perdido e Jacó, até a Rua Barão de Mesquita, no bairro da Tijuca. Neste trecho, não são observadas manchas de inundação frequentes. No trecho a jusante desta galeria, o rio Joana segue em canal aberto até a travessia da Rua Pereira Nunes. Ao longo deste trecho são observados pontos de inundação a partir do cruzamento da Rua. Maxwell com a Rua Uruguai. O Rio Joana volta a ser tamponado ao longo de um pequeno trecho na Av. Prof. Manoel de Abreu, a partir da Rua Pereira Nunes, seguindo novamente em canal aberto, ao longo desta avenida, até a confluência com as Ruas Maxwell e Felipe Camarão, onde ocorrem às manchas de inundação mais frequentes.

A área compreendida entre a confluência das avenidas Prof. Manoel de Abreu e Rua Maxwell, até as proximidades do estádio Célio de Barros, na Praça Emilio Garrastazu Médici, e Av. Presidente Castelo Branco constitui o trecho mais crítico de inundações em galeria fechada até sua foz, no rio Maracanã. Este trecho apresenta importantes restrições de frequentes na bacia do rio Joana. A partir da travessia sob a Av. Presidente Castelo Branco e da linha férrea, o rio Joana segue escoamento, causando o represamento de montante. O estudo hidráulico mostrou que ocorrem restrições devido ao efeito de remanso no desemboque do rio Joana no rio Maracanã, o qual, durante eventos de cheia, ocorre em seção totalmente afogada. Além disso, a galeria no trecho final do Rio Joana, conforme verificado em vistorias de campo, 
apresenta interferências que provocam restrição ao escoamento, tais como o cruzamento de tubulações adutoras.

Foram avaliadas duas alternativas complementares para a redução dos problemas de déficit na bacia hidrográfica do rio Joana, e consequente melhoria no escoamento nos trechos de jusante no rio Maracanã e canal do Mangue: a reservação de montante e o desvio do curso do rio Joana diretamente para a baía de Guanabara.

Ao longo do curso do rio Joana, foi localizada uma área de aproximadamente $6.000 \mathrm{~m}^{2}$, no estacionamento do supermercado Boulevard, na altura da Av. Eng. Otacílio Negrão. Nesta área, foi avaliada a possibilidade de instalação de um reservatório off-line, de volume aproximado de $140.000 \mathrm{~m}^{3}$, que permitiria armazenar as vazões provenientes da bacia contribuinte de montante, cuja área de drenagem é de aproximadamente. $8,0 \mathrm{~km}^{2}$ e a vazão de projeto para TR $=25$ anos é de $70 \mathrm{~m}^{3} / \mathrm{s}$. Outra área de reservação está localizada no Alto Grajaú, próximo à subestação de Furnas, com volume de $50.000 \mathrm{~m}^{3}$, que iria aliviar a calha do Rio Joana a jusante.

O desvio do curso do Rio Joana com mudança do seu exutório do rio Maracanã para a baía de Guanabara é uma alternativa que foi avaliada pela primeira vez em 1993, pelo Eng. Antonio Eulálio Araújo (O Globo, 2010). Este desvio teria a função de aliviar a afluência de vazões ao trecho final do Rio Joana, possibilitando um melhor aproveitamento da calha do rio Maracanã a jusante da foz do Joana, melhorando o escoamento na parte de jusante do rio Maracanã. Desde que a proposta foi apresentada pela primeira vez, alternativas de traçado para o desvio vêm sendo discutidas a fim de possibilitar o melhor aproveitamento e melhor custo benefício.

No presente estudo, o traçado analisado para o desvio do Joana tem por objetivo melhorar o escoamento desde o trecho onde começam os problemas de inundação na bacia do rio Joana, a montante da travessia da linha férrea. A alternativa avaliada prevê a implantação de um desvio feito parte em túnel, parte em galeria, começando na altura do cruzamento da Av. Prof. Manuel de Abreu com a Rua Felipe Camarão, local onde foi registrado o início da mancha de inundação observada. $O$ traçado estudado tem início neste ponto, seguindo, inicialmente, em galeria, no trecho de travessia da linha férrea; em seguida, segue em túnel e, por fim, novamente em 
galeria ao longo da Rua São Cristóvão até o ponto de deságue, na Baía de Guanabara, próximo à foz, no Canal do Mangue. 
6

Detalhamento do projeto: Obras de desvio do Rio Joana com execução de galerias, reforço de calha $e$ intervenções complementares, visando o controle de enchentes da bacia do Canal Do Mangue - Praça da Bandeira

\section{1}

\section{Descrição das Obras}

A derivação do Rio Maracanã para o Rio Joana e do desvio do Rio Joana para a Baía da Guanabara serão compostos das seguintes obras:

\subsection{1}

\section{Galeria de derivação do Rio Maracanã para o Rio Joana}

Esta galeria se inicia na Av. Maracanã e desemboca na galeria de reforço do canal do Rio Joana, com extensão de cerca de 445,00 m e com seção constituída por galeria de concreto de dupla seção de 3,00m de base cada por 2,50 m de altura.

\section{1 .2}

\section{Galeria de reforço do canal do Rio Joana}

A galeria de reforço se inicia no poço de emboque junto à Praça Emílio Garrastazu Médici e termina na Galeria de Derivação, na altura da Rua Felipe Camarão. A galeria de reforço é constituída dos seguintes trechos:

- No trecho inicial, com extensão de 148,00 m, em galeria de concreto convencional com fundação direta, com seção constituída galeria de concreto de dupla seção de 5,00m de base por 3,00 m de altura cada uma das células.

- No trecho final, galeria de reforço, com extensão de 436,00 m em concreto com base de 5,00 m por 3,00 m de altura, a ser executada como complemento do canal existente, com fundação em estacas e parede diafragma atirantada; 


\subsection{3}

\section{Túnel de Desvio do Rio Joana}

O túnel de desvio tem uma extensão total de aproximadamente 2.330,00 m e se inicia após o poço de emboque da galeria de reforço do Rio Joana. Este túnel será executado em trechos em rocha, em solo e em seções mista rocha-solo. São previstas as seguintes seções típicas:

\subsection{4}

\section{Túnel Pelo Método NATM}

Termo utilizado para identificar o novo método austríaco de execução de túneis. O termo NATM é definido como método de execução de túneis em que o maciço do entorno do túnel é integrado ao suporte, formando um grande anel fechado e, portanto, fazendo parte da estrutura portante. Na comunidade técnica, o termo NATM é comumente utilizado para identificar os tuneis executados por etapas com revestimento em concreto projetado.

\section{1 .5}

\section{Programa de Diagnóstico Histórico}

$\mathrm{Na}$ área de intervenção para o trecho de obras a partir da linha férrea, com escavações subterrâneas de profundidades significativas, e pelo fato desta área estar inserida no grupo de possíveis de áreas que contenham vestígios arqueológicos, fazse necessário um trabalho de consultas aos levantamentos bibliográficos e documentos gráficos, disponibilizados em órgãos de preservação, assim como, realização de visitas e vistorias ao longo de todo o respectivo traçado, de forma a legalizar as pesquisas, com todo o material ali encontrado no IPHAN, de acordo com as legislações vigentes.

Apresentamos as intervenções hidráulicas na Bacia Hidrográfica do Canal do Mangue, com vistas à Carta Consulta das obras de reservação nas bacias hidrográficas dos rios Joana e Trapicheiros, com vistas à redução do risco de inundações na bacia hidrográfica. 
Esta parte está vinculada ao Desvio do Rio Joana, apesar de serem obras distintas. Os estudos hidrológicos contemplam a condição de operação integrada do sistema da bacia hidrográfica, considerando para o seu funcionamento otimizado as seguintes intervenções:

- Reservatório RJ-1 (Rio Joana);

- Reservatório RJ-3 (Rio Joana)

- Reservatório RT-1 (Rio Trapicheiros);

- Reservatório RT-2 (Rio Trapicheiros).

- Desvio do Rio Joana;

- Derivação de vazões do Rio Maracanã para o Rio Joana;

- Reforço de galeria no Rio Joana

\section{2}

\section{Estudo de alternativas para a redução do risco de inundações na Bacia Hidrográfica do Canal do Mangue}

Para a adequação das condições de escoamento na bacia hidrográfica do Canal do Mangue com vistas à redução do risco de ocorrência inundação, foram estudadas alternativas de intervenções na bacia hidrográfica, considerando a natureza das causas das inundações e as possibilidades de intervenção disponíveis.

As alternativas de intervenção na macrodrenagem avaliadas foram a reservação, o reforço de galerias e canais e o desvio de cursos d'água. A eficiência de cada alternativa foi avaliada do ponto de vista hidrológico-hidráulico, econômico, geológico-geotécnico, estrutural e de viabilidade de execução, dadas as interfaces com os sistemas urbanos existentes.

A reservação na macrodrenagem constitui uma alternativa de solução estrutural que visa restituir ou fornecer à bacia um amortecimento dos picos dos hidrogramas e um retardo no tempo de concentração da bacia hidrográfica, a fim de promover uma adequação das vazões de projeto às capacidades de escoamento dos canais da macrodrenagem. A reservação artificial é feita por meio de reservatórios de detenção, que armazenam os volumes de cheia durante os eventos de maior 
intensidade, e devolvem estes volumes ao curso d'água, em condições condizentes com a capacidade da calha, por meio de gravidade (reservatórios in-line) ou por bombeamento (reservatórios off-line).

O reforço hidráulico de galerias e canais constitui uma alternativa hidráulica que visa aumentar a capacidade do canal, e que é viável quando há área disponível para tanto e, principalmente, quando sua aplicação não constitui incremento de vazões a jusante, agravando o problema de inundações em bacias adjacentes. No caso da bacia do canal do Mangue, cujo exutório é a baía de Guanabara, esta alternativa torna-se particularmente aplicável, uma vez que tem menor potencial para causar impacto negativo nas áreas de jusante. Da mesma forma, o desvio de cursos d'água com alteração de seu exutório para a baía, em lugar dos exutórios atuais, nos canais da macrodrenagem, também é uma alternativa a ser considerada.

A bacia hidrográfica do canal do Mangue tem suas principais restrições de escoamento nas áreas baixas e em seções restritivas nos canais da macrodrenagem, tais como pontes, travessias e trechos de galeria. As alternativas para a redução dos déficits de capacidade foram avaliadas do ponto de vista da disponibilidade de áreas para intervenções, da eficiência hidrológica e hidráulica, da viabilidade geológicogeotécnica e da análise de custo.

A seguir são discutidas as alternativas de intervenção hidráulico-hidrológica que foram avaliadas para as principais sub-bacias contribuintes do Canal do Mangue.

\subsection{1}

\section{Alternativas de intervenção na bacia do Rio Maracanã}

O Rio Maracanã tem seu início no Maciço da Tijuca e é o curso d'água mais extenso da bacia hidrográfica do canal do Mangue, percorrendo 9,4 km desde a nascente até sua foz, no canal do Mangue. Seus principais tributários são os rios Joana e Trapicheiros, os quais têm seus pontos de deságue localizados na área de baixada da bacia do Mangue, próximo à foz do Rio Maracanã, no canal do Mangue.

Ao longo do curso do Rio Maracanã ocorrem pontos de estrangulamento, os quais geram as manchas de inundação observadas. Os registros apontam que a 
primeira área de armazenamento ocorre nas proximidades na Praça Xavier de Brito, próximo ao cruzamento das Ruas Pinto Guedes e Dr. Octávio Kelly. Mais a jusante, ocorre um novo ponto de inundação registrado na Av. Maracanã, entre o Shopping Center Tijuca e o Colégio Marista São José. Imediatamente a jusante deste trecho, a partir da Rua Deputado Soares Filho, o Rio Maracanã passa a escoar em seção fechada, com um importante estrangulamento localizado na entrada da galeria, o que pode influenciar a formação de inundações a montante da entrada da galeria durante as chuvas críticas.

O rio Maracanã volta a apresentar registro de inundação observada a partir da região do estádio do Maracanã, nas proximidades do cruzamento da Av. Maracanã com a Rua Prof. Eurico Rabelo, até a sua foz, no Canal do Mangue. Neste trecho, o rio Maracanã recebe importantes contribuições de vazão em virtude do deságue dos rios Joana e Trapicheiros.

A alternativa estudada para a bacia do rio Maracanã consiste de uma galeria de derivação que interliga o Rio Maracanã ao desvio projetado para o Rio Joana, através de uma galeria ao longo da Rua Felipe Camarão. Esta galeria teria início na Av. Maracanã, com desemboque na galeria de reforço projetada para o Rio Joana, com extensão de cerca de 470,00 m e com seção constituída por duas aduelas de concreto moldado in loco de 3,00 de base por 2,50 m de altura, com fundação em estacas de concreto pré-moldado. Esta medida possibilitará, além da redução dos problemas locais de inundação, o melhor aproveitamento da calha do rio Maracanã em sua parte jusante, reduzindo os problemas de inundação observados atualmente.

Ressalte-se que a derivação de vazões do Rio Maracanã para o Rio Joana, através da Rua Felipe Camarão, ocorre atualmente, por meio de escoamento superficial. A derivação de vazões do Rio Maracanã virá promover a regularização deste escoamento, por meio da implantação de galeria subterrânea com capacidade para veicular as vazões afluentes, e com desemboque em uma estrutura hidráulica capaz de comportar o afluxo de vazões. 


\section{2 .2}

\section{Alternativas de intervenção na bacia do Rio Trapicheiros}

Os problemas de inundação no rio Trapicheiros remontam ao início do século passado, quando já eram registradas inundações na região da Praça da Bandeira. Com extensão aproximada de 4.600 m, o curso d'água do rio Trapicheiro drena uma área intensamente urbanizada no bairro da Tijuca e Praça da Bandeira. À exceção da região de cabeceira, o curso do Rio Trapicheiros é praticamente todo tamponado, com pequenos trechos em canal aberto.

O primeiro ponto de inundação observada está localizado no início do trecho em galeria no entroncamento da Av. Heitor Beltrão e Rua Silva Ramos com as ruas Prof. Gabizo e Martins Pena, nas proximidades da Praça Afonso Pena. As possíveis causas para a ocorrência desta mancha de inundação são a redução de seção que ocorre a partir da travessia sob a Rua São Francisco Xavier, bem como a restrição de capacidade imposta pela travessia da rua Prof. Gabizo e pela própria entrada na galeria, a partir deste mesmo ponto. Deste ponto em diante o rio Trapicheiros segue em galeria ao longo da Rua Vicente Licínio, até as proximidades da Travessa Soledade, onde ocorre uma bifurcação no curso do Rio Trapicheiros. Neste ponto, ele é dividido nos braços esquerdo e direito; o braço esquerdo segue ao longo da Rua Felisberto de Menezes, em direção ao Rio Maracanã; o braço direito segue ao longo da Rua Barão de Iguatemi, em direção ao Canal do Mangue. O trecho de travessia da linha férrea do braço esquerdo tem seção em canal aberto; todos os demais possuem seções em galeria.

Em ambos os braços direito e esquerdo há registro de mancha de inundação observada. Entre os dois tramos está localizada a Praça da Bandeira, um ponto baixo que, atualmente, constitui um dos principais pontos de inundação da bacia do Canal do Mangue, com grande influência no setor de transportes, uma vez que a Praça da Bandeira é um importante eixo de ligação entre a região central e a zona norte do município do Rio de Janeiro.

É estudada a alternativa de implantação de um reservatório de detenção offline no estacionamento do supermercado Extra, na Rua Heitor Beltrão, com 
capacidade de, aproximadamente, $70.000 \mathrm{~m}^{3}$. A implantação deste reservatório viria aliviar a afluência de vazão a jusante, possibilitando um melhor aproveitamento da calha no trecho em galeria.

Também é avaliada a implantação de um reservatório na Praça da Bandeira. Devido à pequena área disponível, este reservatório teria função de auxiliar na drenagem local desta região, que constitui um ponto baixo de frequentes inundações. O curso do Rio Trapicheiros deverá ser interligado a este reservatório, por meio de uma galeria com início no seu braço esquerdo. O reservatório da Praça da Bandeira também deverá receber a contribuição da sub-bacia local, funcionando para contenção da microdrenagem. O retorno das águas do reservatório deverá ser feito pelo mesmo braço esquerdo do rio Trapicheiros, no trecho que deverá ser reforçado com adequações hidráulicas da galeria existente para possibilitar a veiculação das vazões afluentes. Este reforço nas galerias do trecho de jusante do rio Trapicheiros deverá priorizar o escoamento pelo braço esquerdo do rio, de modo a aliviar a já sobrecarregada calha do Canal do Mangue nas proximidades da foz do Rio Comprido, que constitui outro ponto de inundação observada.

As alternativas avaliadas para o Rio Trapicheiros consistem, portanto, de reservação a montante e reforço de galeria no trecho jusante, com implantação de um reservatório de detenção para a drenagem local na região da Praça da Bandeira.

\section{3}

\section{Esquema hidráulico do sistema proposto}

O sistema de obras hidráulicas proposto para a redução do risco de inundações na bacia hidrográfica do canal do Mangue é composto por reservatórios de detenção, galerias de reforço, galerias de derivação, túnel e galeria de desvio. Este sistema prevê a reconfiguração da macrodrenagem da bacia hidrográfica do Canal do Mangue de modo a possibilitar a veiculação das vazões de projeto para o período de recorrência $\mathrm{TR}=25$ anos. As intervenções propostas estão descritas a seguir.

\subsection{1}

\section{Desvio do Rio Joana}


Desvio do Rio Joana será realizado por meio de um sistema de túnel e galeria de desvio. O trecho inicial será composto por um túnel com início na Praça Pres. Emílio Garrastazu Médici e desemboque na Baía de Guanabara, próximo a foz do Canal do Mangue. Este túnel terá uma seção equivalente a $38 \mathrm{~m}^{2}$ e terá a capacidade de vazão de $100,0 \mathrm{~m}^{3} / \mathrm{s}$. O trecho em galeria irá percorrer a Rua São Cristóvão, com desemboque na Baía de Guanabara, na altura da Av. do Gasômetro, próximo à foz do Canal do Mangue.

O desvio do Rio Joana irá possibilitar que a galeria que compõe o trecho final do Rio Joana possa veicular a vazão remanescente, proveniente das áreas de

contribuição à jusante da embocadura do túnel de desvio. Além disso, o desvio irá comportar parte da vazão do Rio Maracanã - aproximadamente $40 \mathrm{~m}^{3} / \mathrm{s}$, para a recorrência de 25 anos - o que irá aliviar a calha deste rio nos seus trechos mais baixos, que apresentam registro de inundações frequentes.

\subsection{2}

\section{Derivação de vazões do Rio Maracanã para o Rio Joana}

A derivação do Rio Maracanã para o Rio Joana visa reduzir as vazões afluentes aos trechos mais baixos do rio, direcionando a vazão excedente para o sistema de desvio do rio Joana para a Baía de Guanabara.

Esta derivação será feita de modo a aproveitar a diferença de cotas entre os dois rios que ocasiona, atualmente, o afluxo de vazões do Rio Maracanã para o Rio Joana, durante as chuvas de maior intensidade, através de escoamento superficial, ao longo da extensão da Rua Felipe Camarão, desde a Praça Varnhagen até a Av. Prof. Manoel de Abreu.

A construção da galeria de derivação do Rio Maracanã para o Rio Joana irá regularizar o escoamento que atualmente ocorre de maneira superficial na Rua Felipe Camarão.

As obras de reforço de galeria no Rio Joana, no trecho situado entre a Rua Felipe Camarão e a entrada do túnel de desvio, localizada na Praça Presidente Emílio Garrastazu Médici, irão possibilitar a veiculação da vazão proveniente do Rio Joana, somada ao aporte decorrente da galeria de derivação da Rua Felipe Camarão. 


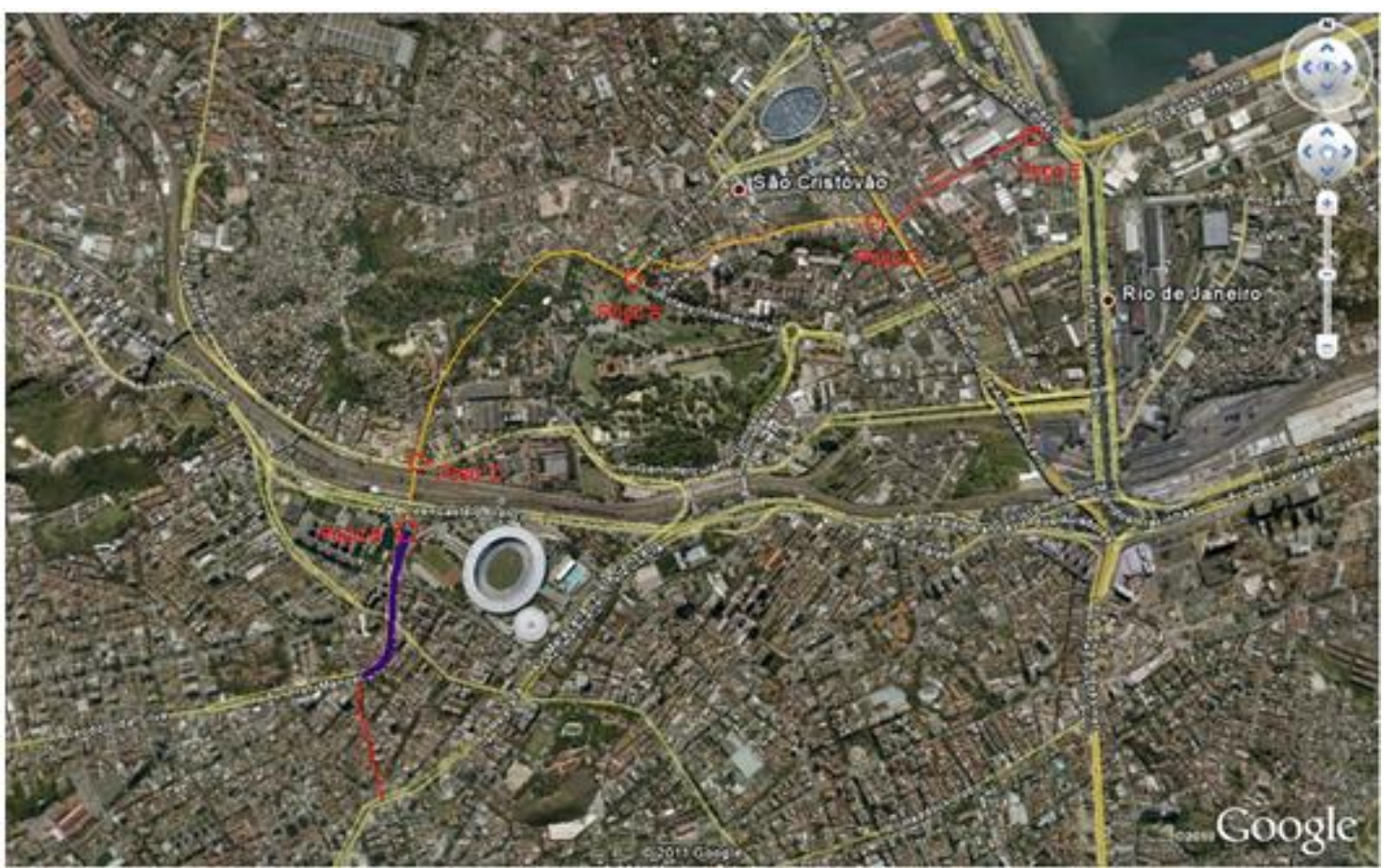

Figura 9 - Visão geral do projeto

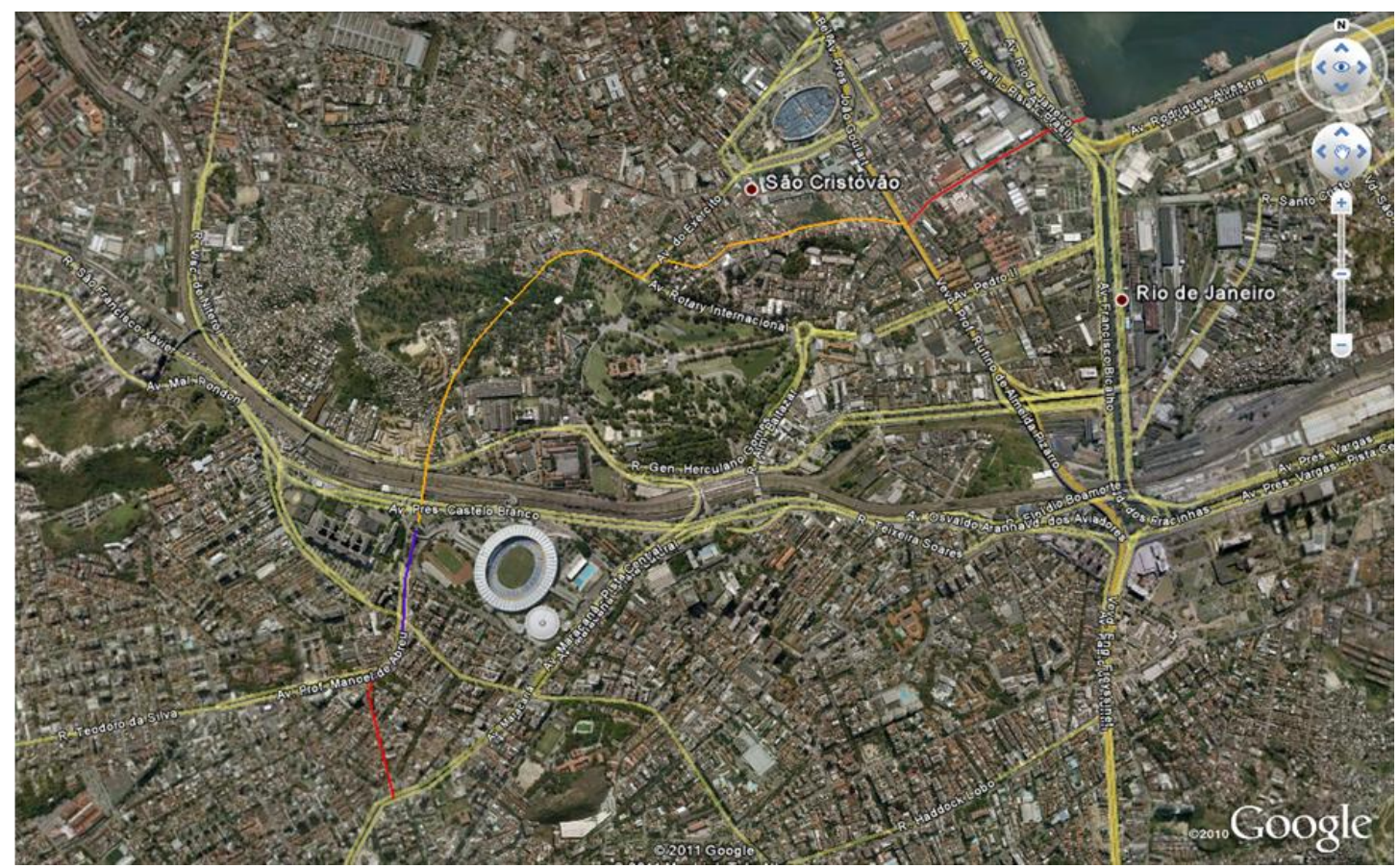

Figura 10 - Transferência de vazão do Rio Maracanã para o Rio Joana num total de $40 \mathrm{~m}^{3} / \mathrm{s}$ 


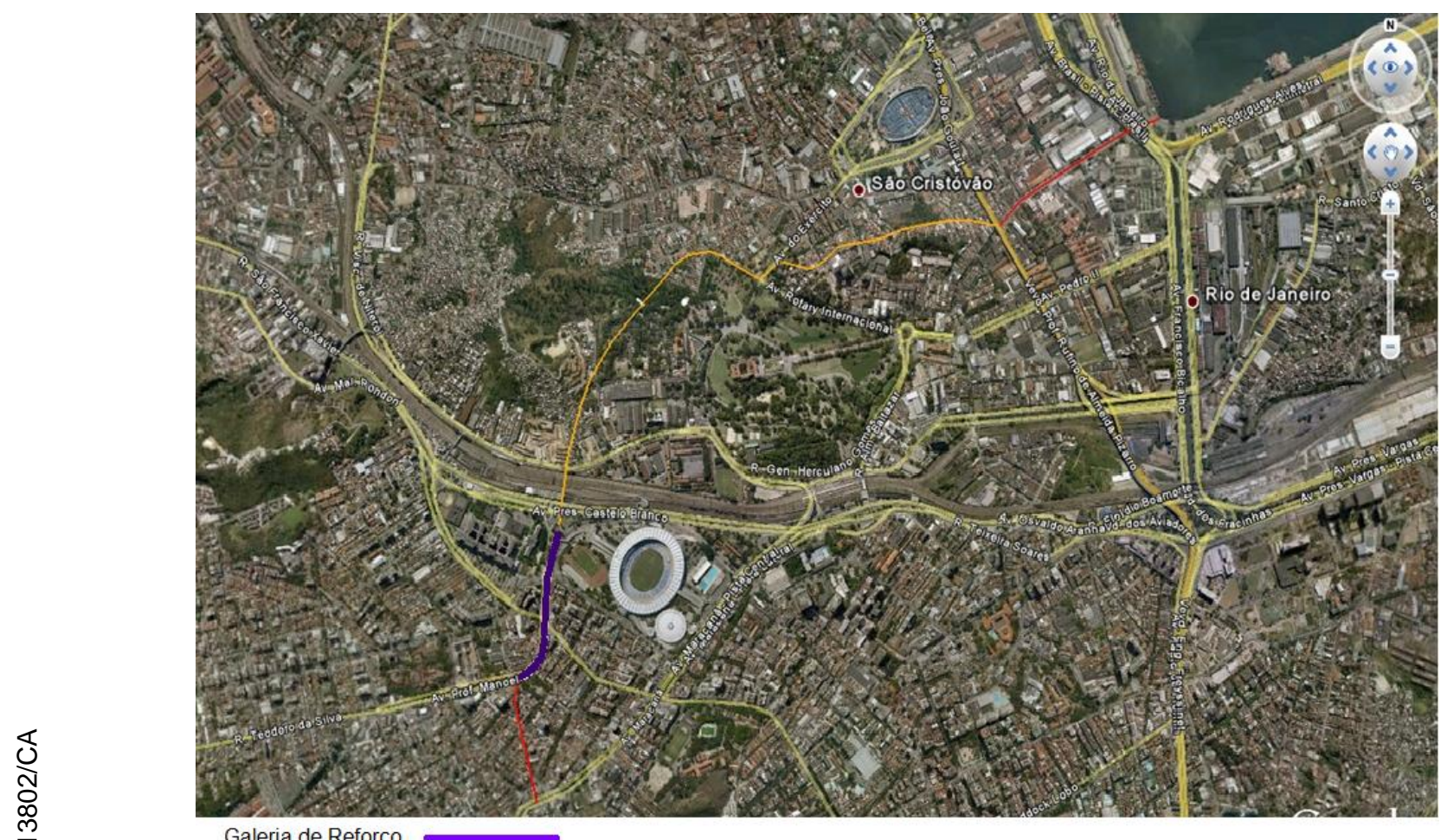

Galeria de Reforço

Figura 11 - Galeria de reforço Joana - Av. Prof. Manuel de Abreu

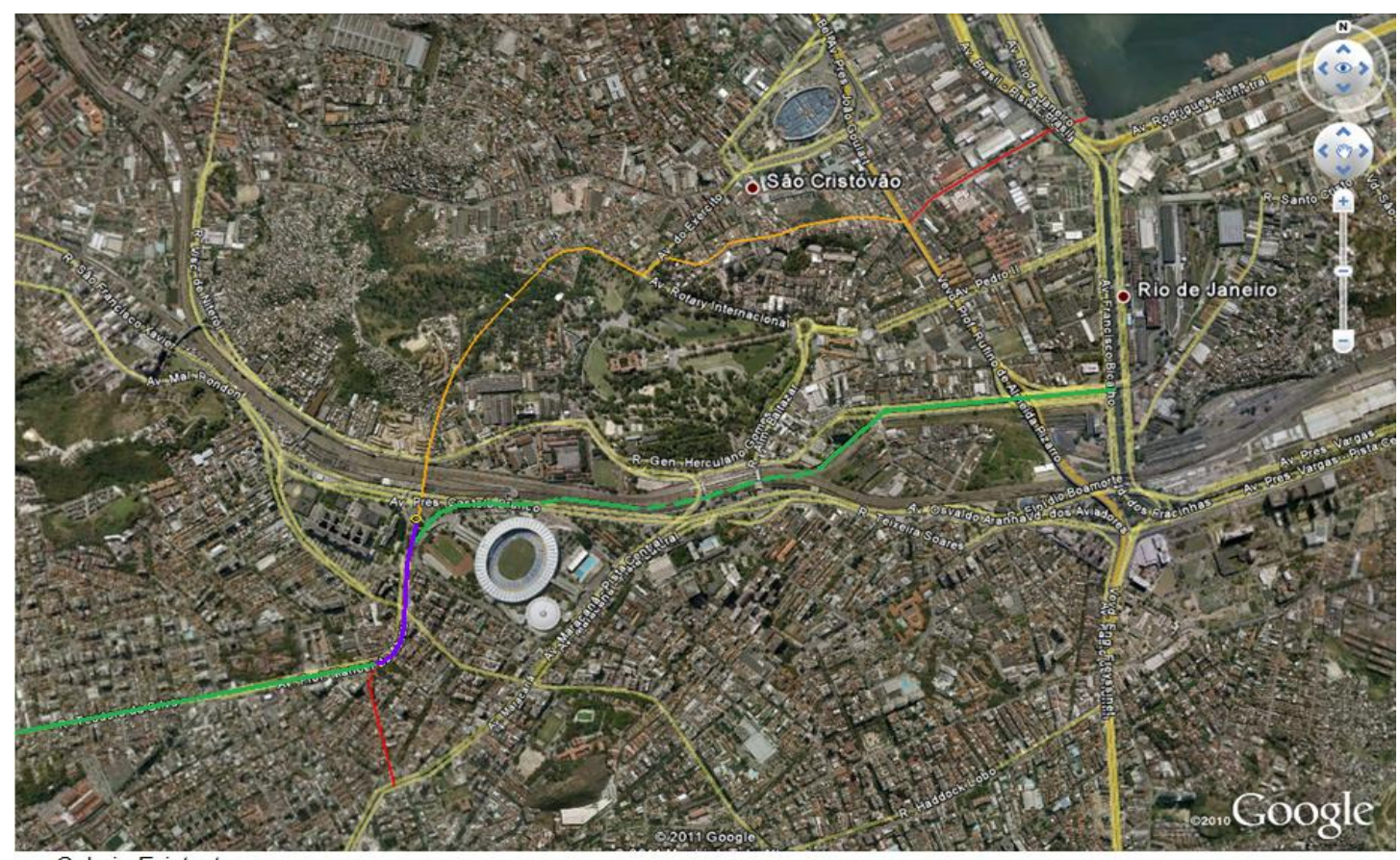

Galeria Existente

Figura 12 - Galeria Existente x Galeria Projetada 


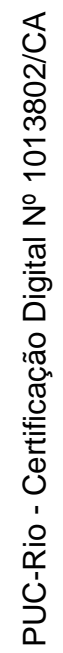

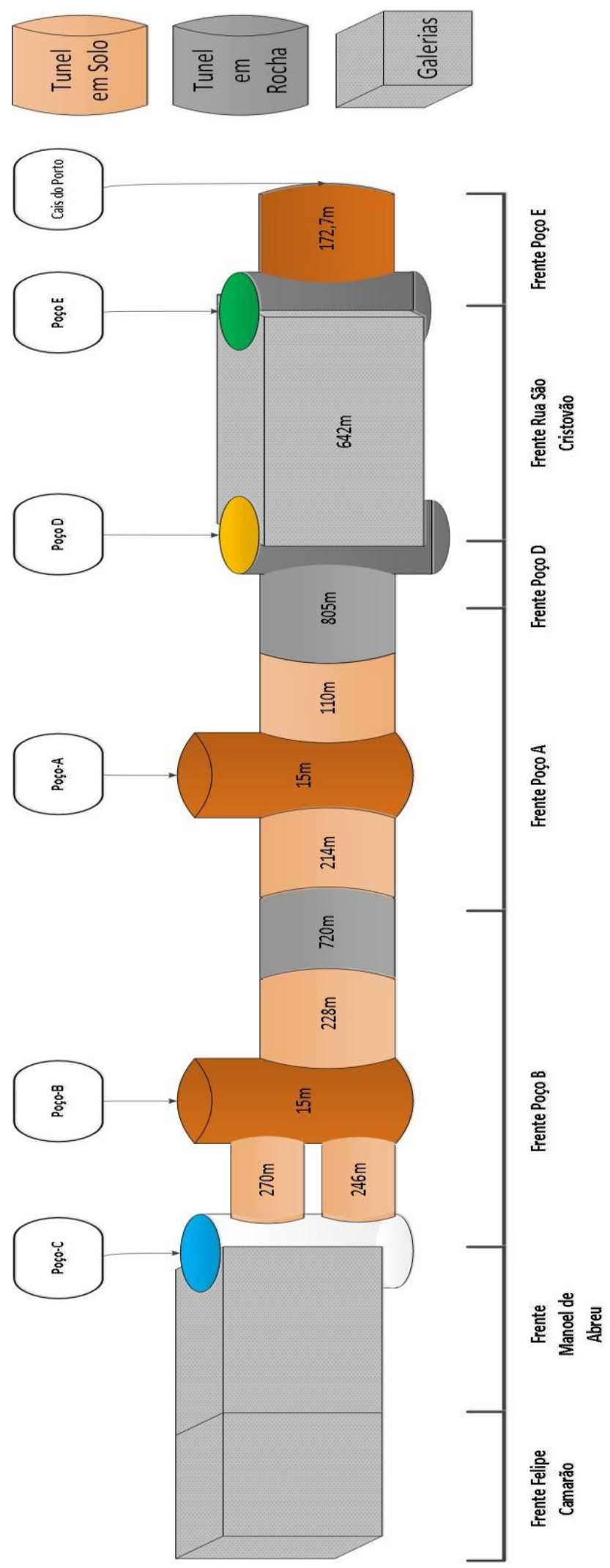

Figura 13 - Diagrama Unifilar do Projeto 


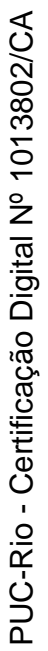

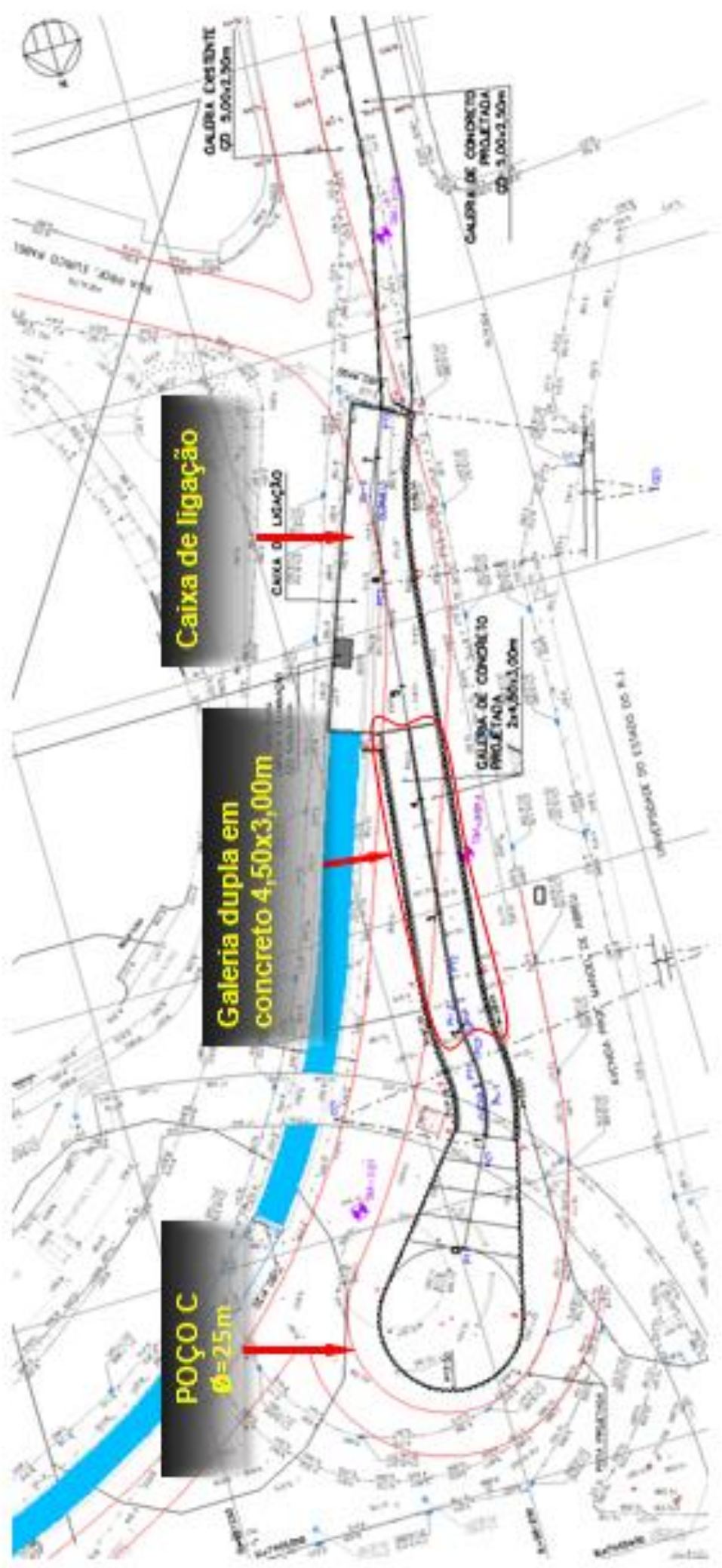

Figura 14 - Ligação Galeria Existente x Galeria Projetada x Poço C inicio do túnel. 


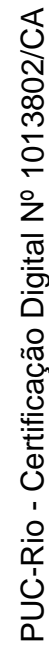

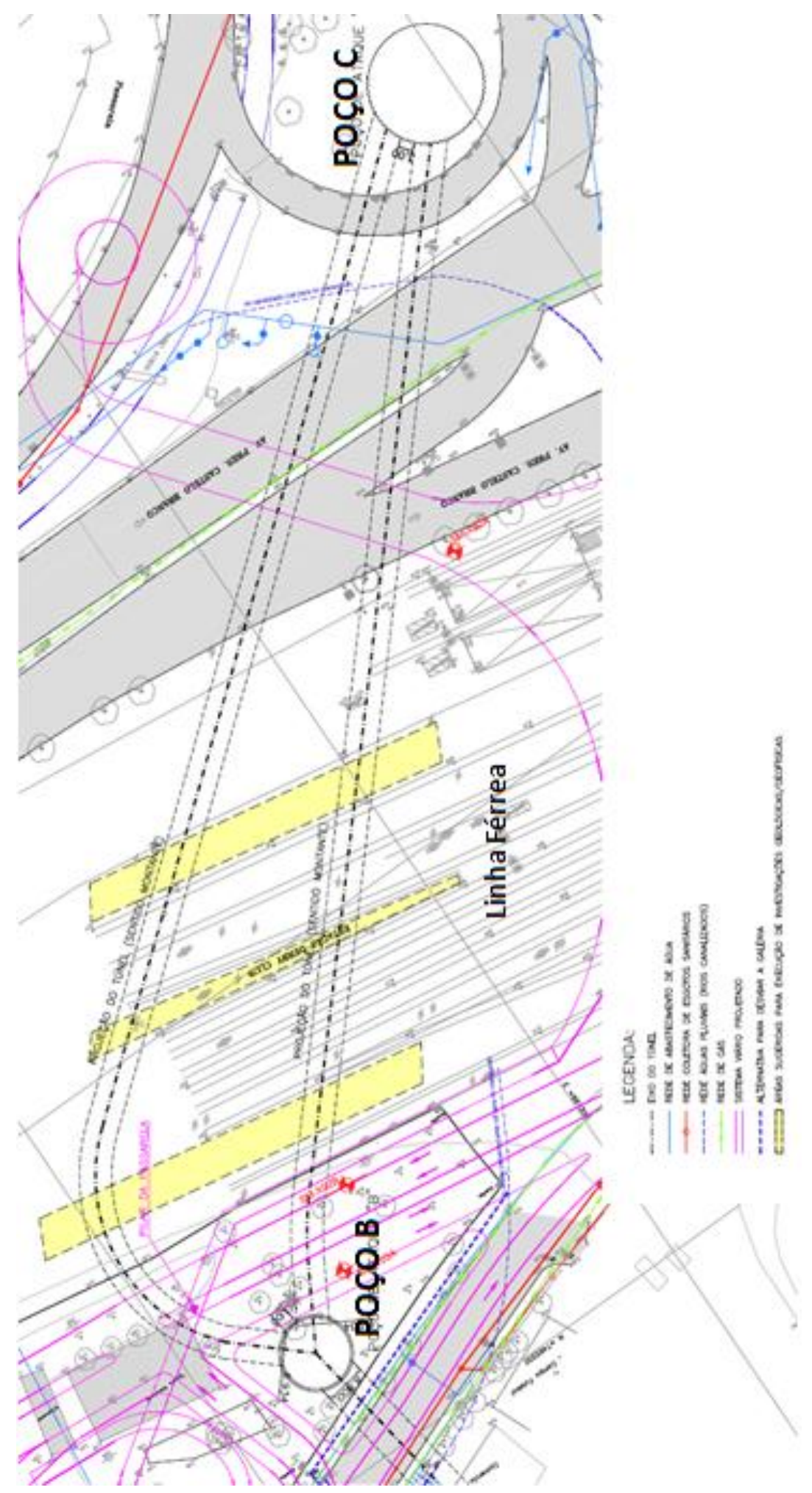

Figura 15 - Poços B e C 


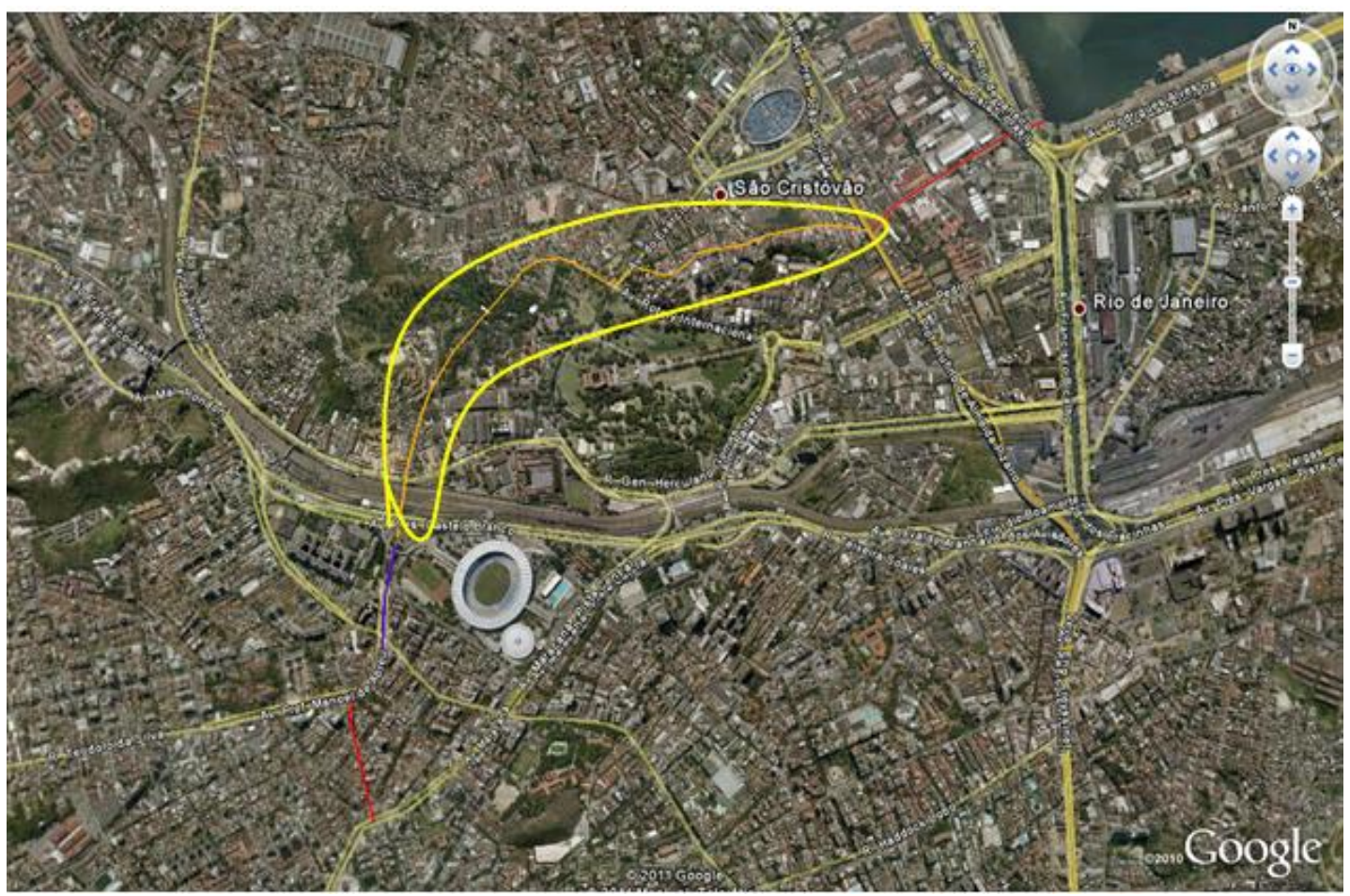

Figura 16 - Túnel Subterrâneo (Extensão de 2.400m)

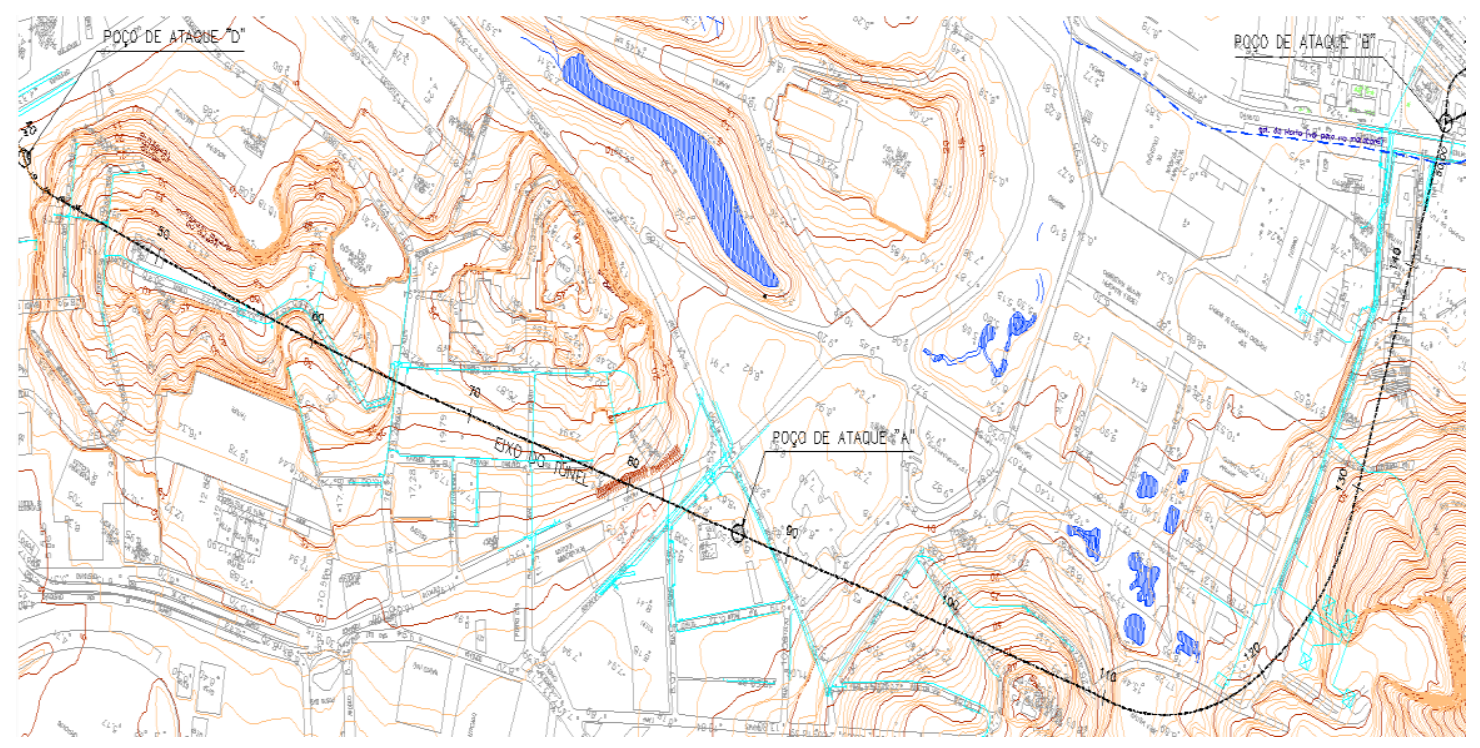

Figura 17 - Planta Baixa - Trecho em Túnel 

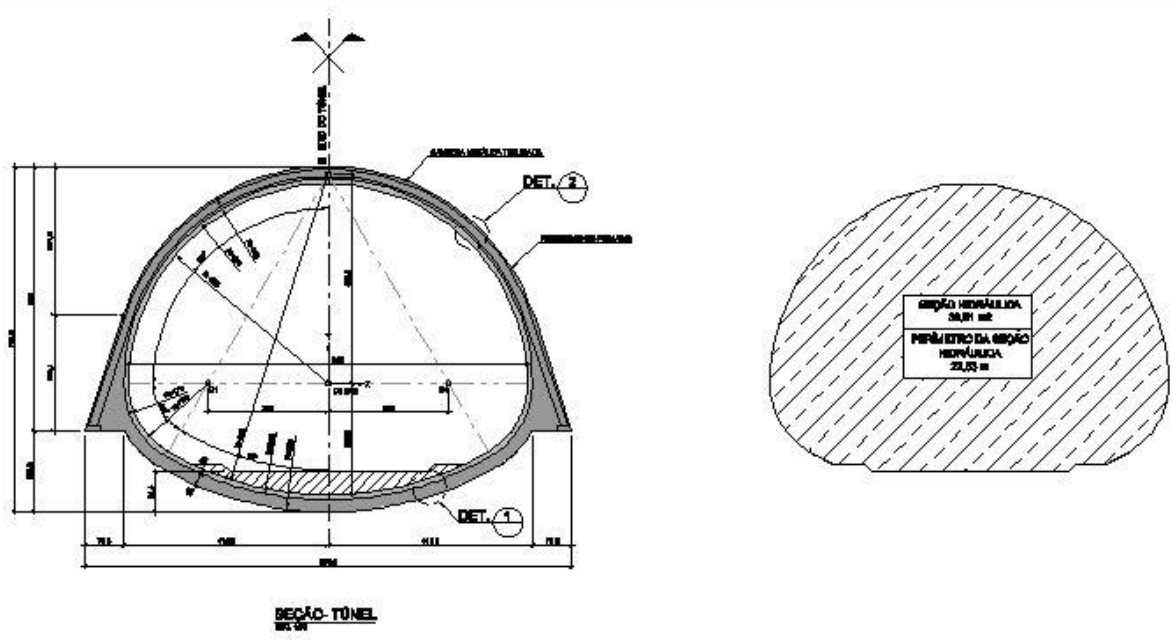

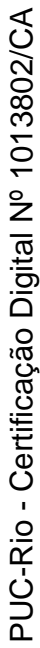
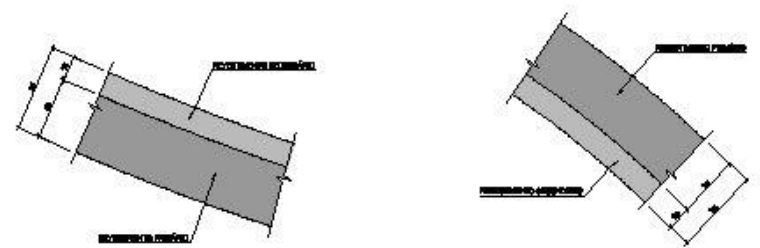

Expe(1)

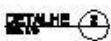

Figura 18 - Seção do Túnel

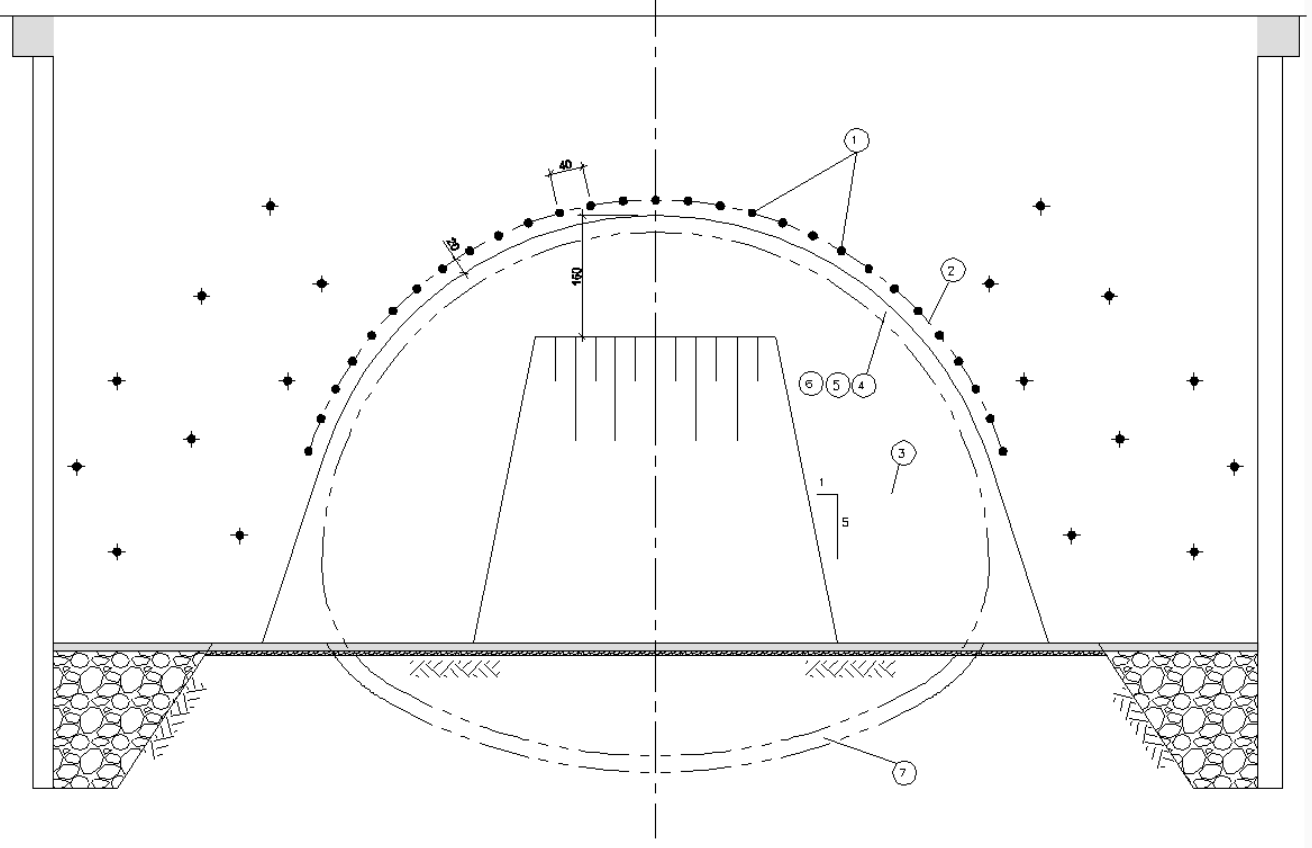

$\frac{\text { CORTE }}{\mathrm{Ex}}$

Figura 19 - Vista Frontal do Emboque do Poço 


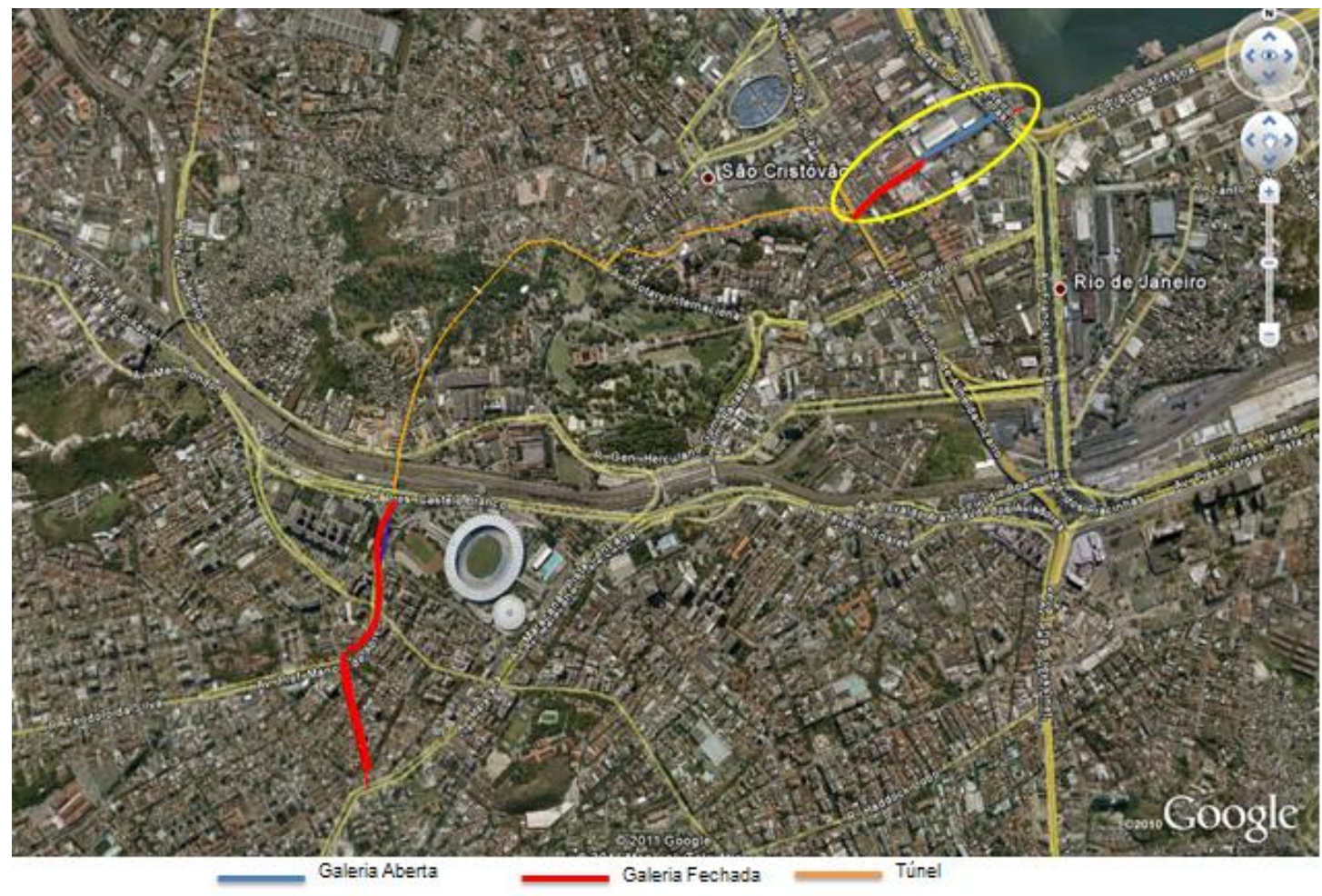

Figura 20 - Rua São Cristóvão - Trecho em galeria aberta e fechada

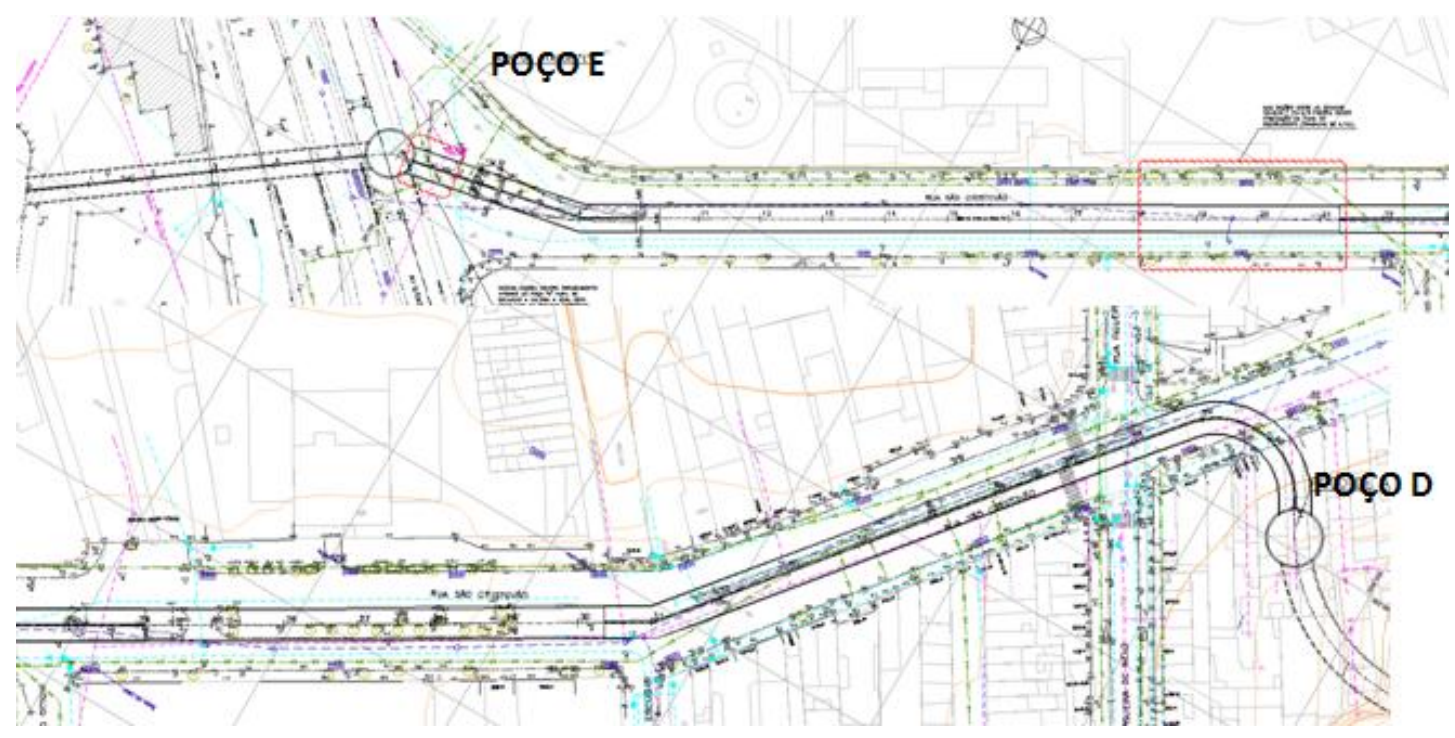

Figura 21 - Planta Baixa - Rua São Cristóvão 


\section{7}

\section{CONCLUSÕES E RECOMENDAÇÕES}

Diante do exposto conclui-se que o Estado tem um papel indutor de sustentabilidade, contudo as práticas ambientais no Brasil vão ao sentido de coibir os impactos sobre o meio natural quando estes já ocorreram, usando meios legais, fiscalizando e reprimindo, muitas vezes de forma ineficaz. Os aspectos ambientais não estão integrados na formulação e na implantação de políticas setoriais e macroeconômicas. Os governantes e tomadores de decisão acabam por agir de forma imediatista, agravando a situação econômica e social decorrente da ausência de planejamento que considerem esses aspectos.

Os centros urbanos do Estado do Rio de Janeiro crescem de forma espontânea, atendendo as necessidades imediatas da população de baixa renda, que por falta de condições de moradia adequada e sem fontes de financiamento, buscam soluções próprias habitando os locais mais insalubres e de risco, como as encostas e faixas marginais de rios e baixadas.

O estudo destacou o problema que já assola a região por muito tempo, ou seja, as enchentes, responsáveis por grandes calamidades e prejuízos, tendo sido agravadas pela urbanização que levou a degradação dos ecossistemas naturais, próprios da topografia existente que se constituía basicamente de resquícios de Mata Atlântica nas encostas e de manguezais nas áreas de baixadas.

Nos estudos contratados pela Fundação Rio-Águas, nem todas as intervenções propostas pelo PDMAP (Plano Diretor de Manejamento de Águas Pluviais) foram até agora executadas. As obras de drenagem correspondem a uma etapa vultosa e causa grandes transtornos na sua execução, principalmente nos trechos em que há favelas. Ressalta-se que qualquer obra de melhoria nessas regiões é bem aceita pela população local, pois mesma se sente valorizada.

Para fins de estudos posteriores, recomenda-se acompanhar a evolução dos processos antrópicos para a bacia estudada e buscar um maior aprofundamento do 
conhecimento das intervenções governamentais que ocorreram na área, o que não foi possível no escopo do presente trabalho. 


\section{REFERÊNCIAS BIBLIOGRÁFICAS}

ABREU, Maurício de A. Evolução urbana do Rio de Janeiro. Rio de Janeiro, IPLANRIO/Zahar, 1987.

BENCHINOL, Jaime L. Pereira Passos, um Haussmann tropical, Rio de Janeiro, Secretaria Municipal de Cultura,Turismo e Esportes, 1990.

BONET CORREA, Antonio, Las Claves del Urbanismo, Ariel: Barcelona, 1989.

CASTRO M. C. P. de; SILVA, H. M. B. da. Legislação e mercado residencial em São Paulo. São Paulo: LabHab /FAU-USP, 1997.

CHOAY, Francoyse. O Urbanismo, utopias e realidade, uma antologia. Tradução de Dafene Nascimento. Perspectiva: São Paulo, 1965.

COVARRUBIAS, J. Disponível em www.estadão.com.br/internacional/guerra/ Oriente/mesopotâmia. Acesso em: 23 de fevereiro de 2013.

DAVIS, M. Planeta Favela. São Paulo: Boitempo, 2007.

DIAS, Maria Odila Leite da Silva. A interiorização da Metrópole e outros estudos. São Paulo: Alameda Casa Editorial, 2005.

IBGE. Instituto Brasileiro de Geografia e Estatística. Disponível em: www.ibge.gov.br. Acesso em: 27 de outubro de 2013.

LESSA, Carlos. O Rio de todos os Brasis. Rio de Janeiro: Record, 2000.

MARICATO. Ermínia. "Limitações ao Planejamento Urbano Democrático" in Temas de Direito Urbanístico 3. Coord. FREITAS, José Carlos de. São Paulo: Imprensa Oficial do Estado MPSP, 2001.

MOTA, S. Urbanização e Meio Ambiente. Rio de Janeiro: ABES, 1999.

ODUM, E. P. Ecologia, Ed. Interamericana, Rio de Janeiro, RJ, 1985.

PLANÁGUA/SEMADS/GTZ, Cooperação Técnica Brasil/Alemanha, Publicado em dezesseis volumes, disponível em cd-room, SEMADS, Rio de Janeiro, RJ, 2001.

REVISTA RIO - ÁGUAS, Fundação Rio-Águas, Rio de Janeiro, RJ, out. /nov., p.4, 1999.

SANTOS, Boaventura de Souza. A Crítica da Razão Indolente - Contra o Desperdício da Experiência. São Paulo: Cortez, 2005 
SANTOS, M. A Urbanização Brasileira. 3 ed. São Paulo: HUCITEC, 1993.

SILVA, E. R., O Curso da Água na História: Simbologia, Moralidade e a Gestão de Recursos Hídricos, Tese de Doutorado, Escola Nacional de Saúde Pública, ENSP/FIOCRUZ, Rio de Janeiro, RJ, 1998.

SIMÕES, A de G. A mortalidade no Rio de Janeiro e seus efeitos na redução da sobrevivência masculina. Dissertação mestrado, Universidade Federal Fluminense, Rio de Janeiro, 2000.

SOUZA. M.L. ABC do Desenvolvimento Urbano. Rio de Janeiro: Bertrand Brasil, 2008.

UERJ, Universidade do Estado do Rio de Janeiro. Projeto de Manejo Hídrico de Bacias Hidrográficas Visando sua Valorização Ambiental, Relatório Resumido, Projeto UERJ/FINEP/REHIDRO Sub-Rede, Rio de Janeiro, RJ, 2002.

UFRJ, Universidade Federal do Rio de Janeiro. Síntese da Evolução da Cidade do Rio de Janeiro de acordo com a História do Brasil, Rio de Janeiro, RJ, 2002.

UNFPA. État de la Population Mondiale 2007: Libérer le Potentiel de la Croissance Urbaine. New York, 2007. Disponível em www.unfpa.org. Acesso em 23 de março de 2013.

WEID, Elisabeth Von Der. O bonde como elemento de expansão urbana no Rio de Janeiro. Fundação Casa de Rui Barbosa, 2000. 